\title{
Problemas jurídicos actuales sobre la vida y la muerte
}

\author{
Pilar Bensusan Martín \\ Profesora Titular de Derecho Administrativo \\ Universidad de Granada \\ "Estar alerta, he ahi la vida; \\ yacer en la tranquilidad, \\ he ahi la muerte". \\ Oscar Wilde
}

SUMARIO: INTRODUCGIÓN: ANTECEDENTES HISTÓRICO-JURÍDICOS SOBRE LA CULTURA DE LA VIDA Y LA MUERTE. BREVE APUNTE. II. APROXIMACIÓN A UNA CONCEPTUACIÓN SOBRE EL SUICIDIO. III. TERRORISTAS EN HUELGA DE HAMBRE CONDENADOS A PENAS PRIVATIVAS DE LIBERTAD. HUELGA DE HAMBRE DE ENFERMOS TERMINALES. IV. EUTANASIA.V. CASO ECHEVARRÍA: DICTAMEN DEL CONSEJO CONSULTIVO DE ANDALUCÍA. VI. TESTAMENTO VITAL. VII. A MODO DE EPÍLOGO

I. INTRODUCCIÓN: ANTECEDENTES HISTÓRICO-JURÍDICOS SOBRE LA CULTURA DE LA VIDA Y LA MUERTE. BREVE APUNTE

"El acto más importante de nuestra vida es la muerte". Ernest Renan

"Cada instante de la vida es un paso hacia la muerte". Pierre Corneille

Desde el inicio de los tiempos, el derecho a la vida ha dominado las relaciones interpersonales y el desarrollo del hombre en sociedad. Con mayor o menor intensidad, se ha venido defendiendo, si no el derecho a la vida de todos, sí el de muchos, culminándose esta idea, que es connatural a la existen- 
cia misma del hombre, desde el momento en que este derecho se extiende a todos los seres humanos.

Pero, ¿qué ocurre con el derecho a la muerte?, derecho absolutamente contrapuesto al de la vida.

Primeramente habría que determinar si actualmente se puede contemplar realmente la posibilidad de la existencia de un derecho como tal a la muerte y cuál sería la regulación jurídica del mismo, si es que verdaderamente existe.

A este respecto deberíamos hacer un somero recorrido por las prácticas y costumbres de otras épocas, o, incluso, de otras culturas distintas de la occidental que han considerado la muerte como un verdadero derecho en algún momento de su historia.

Y es que la actitud de los hombres ante la muerte no ha sido la misma a través de los tiempos; cuando un hombre de hoy habla de su muerte, piensa que si le fuera dado escogería una muerte súbita, sin dolor, como un leve sueño. El hombre del medioevo se sentiría aterrado ante ello, porque, como dice el padre de Hamlet en la famosa obra de Shakespeare, moriría "en la flor del pecado"; por eso el hombre de la Edad Media prefería un tiempo de arrepentimiento y de balance de sus deudas con Dios y con los hombres, inclusive en las oraciones medievales se rezaba "líbranos Señor de la muerte repentina".

Las antiguas civilizaciones sacralizaron la muerte, la domesticaron, queriendo restarle dramatismo e integrarla en un sistema de ritos y creencias que tenían por objeto convertirla en una etapa más del destino, por ello, rechazaban y condenaban el suicidio: el cuerpo del suicida era castigado, arrastrado por el suelo y no tenía derecho a ser sepultado en la Iglesia, sólo en el caso del soldado vencido que se suicidaba por honor, o de otras formas de suicidio como el duelo, se conservaba ese derecho.

En sociedades donde la sacralidad era la cosmovisión vigente, es lógico que el comportamiento suicida se rechazara, pues al hombre no le estaba permitido modificar su destino, que estaba en las manos de Dios, tampoco se le reconocía al ser humano el derecho de imponer a la sociedad la presencia intempestiva de la muerte por una decisión personal, una sociedad así no permitía que el individuo la forzara moralmente ni a ella ni a Dios. 
Pero, a pesar de lo señalado, el suicidio ha estado ligado a la humanidad y sus costumbres.

Es el caso del Japón feudal, concretamente durante el sogunado Tokugawa, en el que el derecho a la muerte de los samuráis se instaura con un código de ética respetado por todos los nobles guerreros o samuráis, y conocido con el nombre de bushido, en japonés, "conducta del guerrero". Igual que las reglas de las órdenes de caballería que prevalecieron en la Europa medieval, bushido se basaba en virtudes tales como la rectitud, la perseverancia, la frugalidad, el coraje, la cortesía, la veracidad y, en especial, la lealtad a los gobernantes y al país. Sólo a través del ejercicio de estas virtudes podía un caballero conservar su honor, y quien lo hubiera mancillado se veía obligado al suicidio mediante el harakiri. Desarrollado hasta su máxima expresión hacia finales del siglo XII, el bushido se convirtió en el siglo XVI en un código escrito. Al quedar abolido el feudalismo, aproximadamente a mediados del siglo XIX, este código fue abandonado, aunque su influencia persiste, sobre todo en el ejército.

En este orden de cosas, no podemos olvidar a los kamikaze de la Segunda Guerra Mundial, palabra japonesa que proviene de kami (dios) y kaze (viento) y que se suele traducir como "viento divino" o "aliento de los dioses". Su origen es una referencia a un tifón que salvó a Japón de una invasión mongola en el siglo XIII, arrasando su flota. En occidente evidentemente se conoce como tales a los pilotos suicidas de la Segunda Guerra Mundial, y, por extensión, a pilotos suicidas o simplemente a suicidas en general.

Japón recurrió a estos pilotos suicidas, teniendo en cuenta la notable diferencia que existía en el potencial bélico entre Japón y los aliados, en los últimos años de la Segunda Guerra Mundial en el Pacífico.

Como expresivamente dijo en aquél tiempo Rikihei Inoguchi, capitán de navío japonés:

"Para nosotros los japoneses, ya estaba completamente claro que nuestro país tendría que afrontar una gravísima crisis, a menos que de una manera u otra lográramos hacer intervenir elementos que fueran capaces, por si solos, de cambiar radicalmente la situación. Así, pues, era muy natural que, en semejantes circunstancias, los combatientes nipones estuvieran dispuestos a sacrificar sus vidas por el Emperador y por la patria".

Los kamikaze eran pilotos que realizaban misiones suicidas, es decir, sin la esperanza de salvar la vida durante la misión. Utilizaban sus aviones a modo 
de proyectil para causar el mayor daño posible al enemigo. Estos pilotos surgieron en el ejército japonés durante la Segunda Guerra Mundial para atacar a los buques estadounidenses que estaban fondeados en aguas del Pacífico Sur. La idea de utilizar a los pilotos como bombas o torpedos humanos tiene su origen en el almirante Takijiro Onishi en octubre de 1944, ante la evidente inefectividad de la marina japonesa contra la superioridad tecnológica de los Estados Unidos de América. En total 34 barcos fueron hundidos y 288 dañados por los pilotos kamikaze (que contaban unos 4.000 entre los Servicios Aéreos Naval y del Ejército). Aunque los resultados de este tipo de ataques eran más simbólicos que prácticos, el efecto psicológico en los soldados aliados era profundo. Los kamikaze se presentaban como voluntarios para realizar dichas misiones, ya que era una manera más que honorable de morir y que suscitaba la admiración general. Este tipo de mentalidad estaba muy arraigada en el pensamiento y dimensión moral japonesas, puesto que el sentido del honor y la obediencia formaban parte del concepto del deber o "Giri" (literalmente, la "Recta Razón"). El "Giri" o deber era uno de los principios del pensamiento japonés, herencia de las ideas morales predominantes en el Japón durante la Edad Media y que son recogidas en el código de conducta de los guerreros samurai, el "Bushido".

Pero el japonés no es el único caso en el que el suicidio se convierte en un derecho a la muerte.

Algunas culturas admitieron el suicidio por motivos religiosos, para encontrar más allá una vida mejor, como en el antiguo Egipto e, incluso, en algunas sectas destructivas de la actualidad.

En las antiguas Grecia y Roma se admitía el suicidio como una forma de haber alcanzado cierta sabiduría; también como rasgo de honor del militar vencido que no se entrega al enemigo, y, en ciertas circunstancias de la vida civil, cuando el noble no toleraba la deshonra o el anciano no deseaba soportar su decrepitud. Entre los hindúes era un deber que la esposa se suicidase al quedar viuda.

En las culturas prehispánicas el suicidio fue una práctica tolerada como defensa en situaciones extremas, hasta el punto de que los Mayas veneraban a una deidad femenina llamada Ixtab (diosa del suicidio). Esta conducta se intensificó durante la época de la Conquista, como alternativa para conservar el honor antes que caer en manos de los españoles.

Aunque en el México antiguo los casos de suicidio fueron tomados en ciertos momentos como un ritual, como en los entierros múltiples o sacrificios 
a manera de acompañamiento político y religioso de algún personaje de alto rango en su viaje al inframundo; también se dio en situaciones donde existía una obediencia ciega de los vasallos hacia sus gobernantes, quienes si les ordenaban quitarse la vida, lo hacían. Esto en la actualidad se considera como un suicido dirigido u homicidio. El mismo caso se dio en las situaciones de guerra, donde el morir en este tipo de hechos, era bien visto, pero en términos morales también representaban suicidios colectivos. Esta conducta de privarse voluntariamente de la vida entre las culturas prehispánicas era un tanto tolerada y se recurría a ella como última vía ante problemas relativos al honor, la vergüenza pública o la desgracia.

Un caso particular ya apuntado era el que se daba entre los Mayas, donde tal comportamiento era menos reprimido, e inclusive rendían culto a Ixtab, diosa del suicidio, representada como una mujer ahorcada con una liana colgando del cielo, quien, según la creencia, era la protectora de quienes decidían quitarse la vida, y los auxiliaba en su trayecto por los diferentes niveles hacia el inframundo. Comportamiento que fue profundamente estudiado por Fray Diego de Landa en Relación de las cosas de Yucatán, que concluye que, al morir, los malos iban a un lugar más bajo del otro que llaman Mitnal, que significa infierno, donde eran atormentados por los demonios y tenían grandes necesidades de hambre, frío, cansancio y tristeza. También iban a la gloria quienes se ahorcaban. Así, había muchos que con pequeñas ocasiones de tristeza, trabajo y enfermedad se ahorcaban para salir de ellas, e ir a descansar a su gloria donde, pensaban, los recibía la diosa de la horca, Ixtab. Las lianas abundantes de las selvas tropicales fueron las principales armas para llevar a cabo dicho acto.

De la interpretación de Fray Diego se puede deducir que entre los Mayas no había una represión como tal contra el suicidio, y que se consideraba un escape válido frente a la insoportable carga de la vida. "No sabemos si eran vistos como honoríficos o simplemente formaban uno más de los sacrificios del panteón maya", dijo.

No así, por la rareza de estas conductas en las fuentes, hace suponer que era algo mal visto en la sociedad Méxica. Casos documentados sobre este pueblo hacen referencia a acontecimientos en los que estaba de por medio el honor o la vergüenza pública. Sobre el suicidio entre los grupos del México antiguo es escasa la información y en algunos casos manipulada, esto, debido a que las fuentes corresponden a la época de la colonización española, en la que esta situación de privarse de la vida voluntariamente fue reprobada y por lo tanto escondida. 
Otro hecho real de suicidio tras la Conquista aparece en los Anales de Tlatelolco. Después de que Hernán Cortés ahorcara a Cuauhtémoc, dos de sus señores se escondieron en los barcos españoles y estando en altamar después de seis días fueron descubiertos y amenazados con ser llevados frente al gran soberano en Castilla, ante esta situación, uno de ellos, de nombre Temilotzin, se arrojó al mar antes de quedar en manos del enemigo.

Aunque no son muchos los casos documentados, se puede concluir para el análisis de las armas utilizadas por los suicidas individuales Méxicas y Mayas, que corresponden a formas simples y antiguas de apropiación del cuerpo y la naturaleza, y que usaron elementos naturales para cometer suicidio, el abandono del cuerpo y mente, cayendo en la inanición o muerte por hambre, ahorcamiento, envenenamiento y ahogamiento.

Otro hecho relacionado con esta práctica fue el suicidio colectivo que se desató como una reacción ante la conquista castellana. Durante esos años el suicidio colectivo fue muy numeroso, ejemplo de ello fue el de los cholultecas, quienes después de haber sido vencidos por los castellanos, subieron a las pirámides y se tiraron al vacío.

En el Occidente cristiano tradicional el rechazo al suicidio llegó a extremos en los siglos XVII y XVIII, sin embargo, en el siglo XIX las prácticas se suavizaron, manteniéndose, sin embargo, la negativa a enterrar a los suicidas en el cementerio. En aquellos tiempos era común ensañarse con el cadáver colgándolo cabeza abajo y arrastrándolo, como en Francia, o, clavándole una estaca en el corazón, como en Inglaterra, donde también se confiscaban todos sus bienes para luego darle un entierro indigno o ninguno. El motivo explícito de estas bárbaras prácticas era que el suicida había incurrido en un pecado gravísimo al desesperar de la ayuda de Dios y al disponer de su vida, facultad exclusiva del Creador. "No matar" era, ante todo, "no matarse", y, este mantenimiento había sido violado de forma evidente y brutal; de ahí el castigo al cadáver, olvidando aquella otra antigua norma bíblica de que la culpa y la sanción no pueden ir más allá de la muerte.

Pero esta actitud tiene raíces ancestrales y duraderas. La explicación, dice el historiador Philipe Ariès, es que las sociedades tradicionales, atemorizadas por la muerte, la "domesticaron", la hicieron entrar en un sistema de creencias y ritos que tenía por objeto convertirla en una etapa más de un destino al que no se podía escapar. Donde la muerte es eminentemente social, el suicida viene a forzar su destino con una decisión individual, y, como no se puede admitir esa afrenta, se la castiga. En cambio, se prevé cierta solemni- 
dad para los suicidios por honor, sobre todo de los militares, y para otras formas de suicidio, como el duelo. No obstante, el rito mantiene el control sobre las conductas.

Fue, no obstante, a partir del siglo XIX cuando se perdió el sentido de socialización del suicidio, inserto en la ritualidad. La sociedad emergente rechazó aquel paradigma medieval. La muerte fue liberada y pasó al dominio privado, el cadáver era velado en la casa y sepultado en familia, y en ese sentido la muerte pasó a depender cada vez más de la voluntad del individuo. De este modo, la sociedad occidental se había desvinculado de la muerte y del suicidio en particular.

El suicidio era, tiempo atrás en Occidente, como se ha visto, algo vergonzoso para la familia; era sinónimo de debilidad, de enfermedad, de conducta inadecuada y por ello pocos o casi nadie lo daban a conocer. Actualmente las cosas son distintas, ya que este acto se ve como un síntoma de enfermedad y se acepta, se denuncia, lo que ha aumentado las cifras de manera alarmante. Es un problema en el que parece haber consenso entre sociólogos, psicólogos, psiquiatras, antropólogos y demógrafos, cuando lo consideran como un rasgo de la modernidad, uno de los males del siglo. Según el psiquiatra español Luis Rojas Marcos, en todas las sociedades y culturas hubo siempre un número relativamente constante de personas que ponen fin a su vida, y otras que lo hacen pero que sus familias lo disimulan o esconden para eludir el tabú que pesa sobre el hecho. La Organización Mundial de la Salud afirma que alrededor de 1.200 personas se suicidan diariamente en el mundo, y que, por cada una de ellas, veinte lo intentan sin éxito.

\section{APROXIMACIÓN A UNA CONCEPTUACIÓN SOBRE EL SUI- CIDIO}

"El suicidio sólo debe mirarse como una debilidad del hombre, porque indudablemente es más fácil morir que soportar sin tregua una vida llena de amarguras".

Johann Wolfang Von Goethe

"La muerte es un castigo para algunos, para otros un regalo, y para muchos un favor".

Séneca

El suicidio (del latín sui caedere, matar a uno mismo) es el acto de quitarse la propia vida. Muchas religiones lo consideran un pecado, y en algunas ju- 
risdicciones aún se considera un delito. Por otra parte, algunas culturas lo ven como una forma honorable de escapar de algunas situaciones humillantes, sin escapatoria o dolorosas en extremo. Para considerarse suicidio, la muerte debe ser un elemento central y el motivo del acto, y no sólo una consecuencia casi ineludible. Así, los hombres bomba y los mártires no son considerados suicidas, dado que unos mueren como consecuencia de la explosión que ellos mismos provocan y los otros se sacrifican en nombre de una creencia. Tampoco son suicidas los que se sacrifican por otros en caso de emergencias ni los soldados que luchan en una guerra, y, en estos casos, los muertos no son proscritos por la religión ni por la ley. En el caso de que el suicidio tenga consecuencias legales, la ley recoge que debe haber prueba de intención de morir así como la propia muerte para que el acto sea considerado un suicidio. Puede que dicho proceso sea costoso en caso de minusvalía y tenga que depender de los demás, donde están entrando en una dinámica de cómplice de suicidio posiblemente penado con cárcel.

En muchos países si un suicidio puede ser evitado por otra persona, es algo que puede y debe hacerse, porque, en caso contrario, podría ser considerado como un caso de no asistencia a persona en peligro, lo que está tipificado como delito en diversas legislaciones, ya que, por ejemplo, un intento de suicidio podría ser debido a un estado de locura transitorio, a un estado depresivo muy grave o a otras situaciones análogas.

Por su parte, la Teología dice que mientras para algunos el suicidio consiste en "darse la muerte directamente a sí mismo"; para otros, simplemente es "darse la muerte a sí mismo", y aclara que, aunque ambas opiniones son semejantes, encierran matices distintos. Mientras que para los primeros el suicidio directo es siempre intrínsecamente malo, para los segundos, el suicidio directo es siempre pecaminoso, pero el suicidio indirecto no lo es. Precisamente, debemos entender que el suicidio directo es aquel en que el ser humano busca mediante un acto que de suyo es capaz de causarla; mientras en el indirecto, la persona se da muerte sin procurarla libremente.

Una clasificación posible de las tantas que se pueden hacer es la que divide los suicidios en:

- Los vicariantes: se adelantan o aceleran el acto de la muerte que se vislumbra en un futuro, con la justificación de que no hay esperanzas y sólo creen ver a su alrededor sufrimientos y nada puede compensar el período de espera. 
- Los perfeccionistas: no toleran cualquier disminución de los atributos a su persona, lo mismo en la belleza que en la potencia sexual, o un defecto cualquiera, menoscabo económico o social, o la pérdida del poder y prestigio.

- Los hedonistas: no soportan nada que constituya un impedimento o una disminución del placer de predominio sensual.

- Los transicionales: ante ciertas crisis vitales de transición inevitables, optan por el suicidio.

- Los sintomáticos: dependen de una enfermedad mental, psicosis, confusión mental, demencia y depresión.

Desde el punto de vista sociológico, hay que destacar al sociólogo francés Emile Durkheim y a su voluminosa obra El suicidio, publicada en 1897, en la que afirma que los suicidios son fenómenos individuales, que responden esencialmente a causas sociales. Las sociedades presentan ciertos síntomas patológicos, ante todo, que la integración o regulación social sean excesivas o insuficientes para el individuo en la colectividad. Por tanto, el suicidio sería un hecho social. Así, Durkheim se propuso desmontar los soportes de la condena moral al suicidio. Analizando numerosas series estadísticas, formula la teoría de que es el contexto social el que, con mayor peso, influye sobre la decisión de un suicida. Esto es, que el índice de suicidios puede ser indicador del estado de disolución de una sociedad. Así, concluye también señalando que las sociedades que ejercen una considerable influencia en el individuo lo contienen y lo preservan de una decisión trágica, y que, a mayor adhesión a las sociedades, religiosa, en primer lugar, doméstica, en segundo, y, política, en tercer lugar, existe una menor inclinación a darse ese fin.

Durkheim comienza ya su estudio en 1835 con una definición de suicidio como: Todo caso de muerte que resulta directa o indirectamente de un acto positivo o negativo realizado por la víctima misma, y que, según ella sabía, debia producir este resultado. Ejemplo de un acto positivo: dispararse en la cabeza; ejemplo de un acto negativo: rehusar a ingerir cualquier medicina hasta dejarse morir.

Durkheim distingue cuatro clases de suicidios:

1. El suicidio egoísta, típico de sociedades deficientes o con carencia de integración social. Se produce cuando un individuo afirma su individualidad contra o al margen de su sociedad de referencia.

2. El suicidio altruista, característico de sociedades con alto grado de integración social, y que es motivado por fidelidad a las normas de la sociedad o 
para hacer bien al propio grupo, como pueden ser la familia, la patria, el partido... Este suicidio es el típico de los militares.

3. El suicidio anómico, característico de falta de regulación social (anomía), o sea, las normas sociales no son interiorizadas como propias por parte del individuo. Por tanto, se da en aquellos supuestos en los que las normas de la sociedad están tan relajadas o alteradas o, incluso, cuando han perdido su vigencia, que el sujeto no encuentra motivos para vivir, no se siente sostenido. Es el caso, por ejemplo, de los suicidios por crisis económicas, por divorcio o por viudez.

4. En nota, a pie de página, Durkheim agrega un cuarto tipo de suicidio opuesto al tercero, el suicidio fatalista, que es el causado cuando existe un alto grado de regulación social o por el exceso de reglamentación, como el de los esclavos y el de aquéllos "cuyo porvenir está despiadadamente limitado". Es sabido que entre las mafias rigen códigos morales propios muy fuertes. Una de sus normas obliga al suicidio en caso de concurrir ciertas condiciones como, por ejemplo, caer preso o ser descubierto como parte de la red. Las sanciones para quien no cumple ese deber son peores que el propio suicidio, puesto que afectan a la familia de forma muy cruel e inevitable. En este caso, el suicidio sería al mismo tiempo altruista y fatalista.

Las explicaciones sociales no pueden dar cuenta con seguridad, dice Rojas Marcos, de por qué "el índice de suicidios en Hungría es veinte veces más alto que en México, en Copenhague es el tripe que en Nueva York, y, en España se ha duplicado en la última década. Tampoco entendemos por qué en Estados Unidos los blancos se suicidan más que los negros, los ricos más que los pobres, o los lunes de primavera son los días más fatídicos. En el fondo, la mayor incógnita es que, bajo las mismas condiciones sociales, unas personas se quiten la vida y otras no".

Otro clásico de la misma corriente de Durkheim es Maurice Halbwach y su libro Las causas del suicidio, de 1930.

Otro francés, Jean Baechler, en su obra Los suicidios, de 1975, vino a desmontar toda la teoría social de Durkheim. Para él, el suicidio es independiente de la sociedad; no así el "mito del suicidio", la obsesión por el tema es moderna, y, aún más, romántica, del siglo XIX. Para Baechler, hay que separar los suicidios de los intentos de suicidios, cada vez más frecuentes. Éstos aumentan porque aumenta la atención que se les presta y ése es el objetivo de muchos suicidas fallidos. Esto convierte al intento en chantaje. La tendencia tiene que ver con la condición actual de la juventud, convertida en grupo social permanente por la sociedad Occidental, materializándose en la realidad de una juventud acosada por las ideas de éxito, de consumo y de la belleza perfecta. 
Según Baechler, el suicidio tiene relación con la noción de fracaso. Mientras que en las sociedades tradicionales las personas hacían su balance frente a la muerte, en las sociedades modernas, a veces, se adelanta ese momento incluso hasta la adolescencia. Ante los desafíos y las dificultades de la vida, algunos plantean una estrategia de poder, es decir, de vencerlos, y otros una estrategia de dependencia, o sea, de pasividad con la finalidad de conciliarse y acomodarse. Cualquiera de estas actitudes puede llevar a la conciencia del fracaso total, o al "semifracaso", que aún deja una esperanza, en este caso, se apela a la advertencia, al intento de suicidio, y es aquí donde se proponen actuar los servicios de prevención y ayuda al potencial suicida.

Según los psicólogos, numerosos suicidios pueden provenir de decisiones profundas, muchas veces debidas a deficiencias en ciertas sustancias químicas del cerecbro, como la serotonina, que puede ser administrada por el médico, lo que hace más trágico que se llegue al hecho fatal. En este campo se ve el suicidio como un impulso autodestructivo, estrechamente ligado con otros mecanismos de lento efecto, como las adicciones, las existencias rutinarias y sumergidas en la desidia y el abandono de sí mismo, o las vidas enajenadas por andamiajes de mentira y autoengaño; en estos casos, la persona deja paulatinamente de ser ella misma.

El suicidio no sólo es trágico, es la tragedia misma, sin remedio y sin explicación. Detrás de sí deja una estela de confusión, dolor más intenso que el de la muerte natural, pena, sentimientos de haber sido traicionados y, al mismo tiempo, de ser culpables. A veces, de sordo rencor. La vida de los sobrevivientes queda sellada por esa tragedia, nunca será igual, nunca será normal, jamás se cerrará la herida. La angustia será un sedimento removido de tanto en tanto, siempre presente.

Pero el suicida no debe ser condenado por los que se quedan. Es víctima de sí mismo. Hay que considerarlo con piedad, esa actitud muchas veces olvidada, con amor por la debilidad, la angustia o la impotencia que no conocemos. En el peor de los casos, cuando el suicida es a la vez un asesino o un delincuente, deberá de comprenderse que no puede ser reducido a su crimen, como dice Edgar Morin, y, menos aún, a su autocrimen: "Él es mucho más que eso, es una persona, y sólo Dios sabe qué luchas tuvo que enfrentar y con qué fuerzas. $Y$ sólo Dios sabe si ha sido capaz, en el instante final, de perdonarse a si mismo, de perdonar a los demás y de entregarse, de todas maneras, a la misericordia divina".

Desde el punto de vista del Derecho, sin embargo, sí existe una condena aquí en la Tierra relacionada con el suicidio. Evidentemente, al que se suicida 
es imposible condenarlo puesto que la muerte le lleva a su inexistencia como sujeto susceptible de derechos y de obligaciones; tampoco existe condena para el que fallidamente lo intenta. Pero al inductor y al cooperador necesario sí que se les castiga por la ley.

El Código Penal español, aprobado por Ley Orgánica 10/1995, de 23 de noviembre, sólo contempla un artículo a este respecto, concretamente el 143, que reza así:

"1. El que induzca al suicidio de otro será castigado con la pena de prisión de cuatro a ocho años.

2. Se le impondrá la pena de prisión de dos a cinco años al que coopere con actos necesarios al suicidio de una persona.

3. Será castigado con la pena de prisión de seis a diez años si la cooperación llegara hasta el punto de ejecutar la muerte.

4. El que causare o cooperare activamente con actos necesarios y directos a la muerte de otro, por la petición expresa, seria e inequívoca de éste, en el caso de que la víctima sufriera una enfermedad grave que conduciría necesariamente a su muerte, o que produjera graves padecimientos permanentes y difíiles de soportar, será castigado con la pena inferior en uno o dos grados a las señaladas en los números 2 y 3 de este artículo".

Este último, el supuesto del artículo 143.4 se refiere a la eutanasia, pero ésta es cuestión que se analizará más adelante, dada la repercusión ética y social que conlleva.

Antes de finalizar este somero análisis del suicidio, sobre el que las disquisiciones y reflexiones son infinitas, puede referirse, desde el punto de vista jurídico, la cuestión de los conductores suicidas, es decir, aquellos que mediante la conducción de un vehículo a motor o de un ciclomotor, y con consciente desprecio por la vida de los demás, no sólo lleven a cabo su propia muerte sino también la de los demás que pudiesen viajar en vehículos con los que intencionadamente colisionan. Es inevitable que al conductor suicida que cumple con su finalidad es imposible castigarlo, pero sí a quien queda vivo tras llevar a cabo semejante conducta. Su regulación penal aparece en el artículo 384 del Código Penal, que dice:

"Será castigado con las penas de prisión de uno a cuatro años, multa de seis a doce meses y privación del derecho a conducir vehiculos a motor y ciclomotores por tiempo superior a seis y hasta diez años, el que, con consciente desprecio por la vida de los demás, incurra en la conducta descrita en el artículo 381".

Artículo que señala que: 
"El que condujere un vehículo a motor o un ciclomotor con temeridad manifiesta y pusiera en concreto peligro para la vida o la integridad de las personas, será castigado con las penas de prisión de seis meses a dos años y con privación del derecho a conducir vehiculos a motor y ciclomotores por tiempo superior a uno y hasta seis años.

En todo caso, se considerará que existe temeridad manifiesta y concreto peligro para la vida o la integridad de las personas en los casos de conducción bajo los efectos de bebidas alcohólicas con altas tasas de alcohol en sangre y con un exceso desproporcionado de velocidad respecto de los límites establecidos".

Pero el conductor suicida no siempre tiene la intencionalidad de acabar, al mismo tiempo que con la suya, con la vida de los demás, a ello se refiere el párrafo segundo del artículo 384, para el supuesto, claro está, de su superviencia:

"Cuando no se haya puesto en concreto peligro la vida o la integridad de las personas, la pena de prisión será de uno a dos años, manteniéndose el resto de las penas”.

De todas formas, no deberá nunca confundirse al conductor suicida con el conductor homicida, en el que la intencionalidad es sólo y exclusivamente la de acabar con la vida de terceros y no con la suya propia. De todas formas, la mayoría de las veces en que en la conducción se producen homicidios, son evidentemente de manera involuntaria. Pero esta cuestión ya no entra dentro del presente estudio, aunque para una mayor comprensión de lo regulado en el artículo 384, es interesante acudir al Preámbulo de la Ley Orgánica 3/1989, de 21 de junio, génesis del mismo, en cuanto se refiere a los conductores homicidas y a su posición intermedia entre el delito de riesgo y el de tentativa de homicidio.

No quisiera acabar este aspecto sin referir las elocuentes palabras sobre el estado de la cuestión de Mirentxu Corcoy Bidasolo y de David Carpio, en La llamada conducción "suicida" y la responsabilidad de la víctima (a propósito de la Sentencia del Tribunal Supremo de 17 de noviembre de 2005), (Revista Tráfico, La Ley, número 101, mayo de 2007):

"Es de lamentar la falta de una necesaria comunicación, entre juristas prácticos y teóricos, para una mayor certeza y seguridad en nuestro Estado de Derecho. Entiéndase bien, esta denuncia trasciende al mero prurito intelectual por lograr influencia o simplemente una sentencia del TS más acorde con la elevada teorización de la dogmática española. Nuestro sincero anhelo va más allá de poner de manifiesto la insuficiente motivación jurídica, mostramos nuestra preocupación por la falta de sintonía general entre la dogmática penal y los miembros de la más alta jurisdicción penal. Asumiendo la posibi- 
lidad de encontrarnos ante un supuesto de culpa compartida, es probable que uno de los motivos que auspicien el desencuentro entre juristas teóricos y técnicos, tenga que ver con la dificultad que conlleva el empleo de un lenguaje excesivamente criptico producido por un nivel de abstracción, a veces innecesario, en el que las teorias jurídicas son elaboradas. Su suprema función ordenadora en la interpretación jurídica, que creemos debe ostentar como vértice de la judicatura española, requiere de una depurada argumentación capaz de garantizar la racionalidad y de suscitar el consenso en torno a sus decisiones”.

\section{TERRORISTAS EN HUELGA DE HAMBRE CONDENADOS A PE- NAS PRIVATIVAS DE LIBERTAD. HUELGA DE HAMBRE DE EN- FERMOS TERMINALES}

"En las modernas metrópolis la vida suele considerarse un bien de consumo más, un bien material susceptible de ser comercializado y manipulado en función de las conveniencias personales" Juan Pablo II

El caso de los terroristas en huelga de hambre, como en 1989 sucedió en España con miembros del grupo terrorista GRAPO, aunque, sin duda alguna, el caso más relevante ha sido el protagonizado por De Juana Chaos, terrorista de ETA, de cuya huelga de hambre se hizo eco la prensa internacional, ha llevado al Tribunal Constitucional (SSTC 120/1990, de 27 de junio; $137 / 1990$, de 19 de julio y 11/1991, de 17 de enero) a analizar el alcance de las "limitaciones a los derechos fundamentales de internos que se colocan en peligro de muerte a consecuencia de una huelga de hambre reivindicativa", llegando a la conclusión de que las referidas limitaciones "podrían resultar contrarias a esos derechos si se tratara de ciudadanos libres o incluso internos que se encuentran en situaciones distintas", ello, como señala Andrés Ollero en su estudio Derecho a la vida y Derecho a la muerte (1994), "no evita, sin embargo, que los pronunciamientos del Tribunal sobre la vida, la muerte y la consideración jurídica que ambas puedan merecer como consecuencia de la libre autodeterminación de un sujeto, alcancen notable relevancia. El fondo del debate exige abordar, por una parte, cuál es el alcance de la legítima intervención de los poderes públicos en la esfera de la autonomía personal; por otra, precisar -como límite o contrapeso de lo anterior- en qué condiciones el juego de la libre autodeterminación individual se convierte propiamente en derecho". "Sobre el primer aspecto -continua- planea la sombra del llamado paternalismo estatal, traducido en una invasión de derechos individuales, llevada a cabo -para mayor mérito- 
en supuesto beneficio, directo o indirecto, de quien ha de soportarla. Sobre el segundo, la opción entre una concepción de los derechos emparentada con el voluntarismo individualista -que remite al contractualismo como único posible fundamento de cualquier condicionamiento de la libertad- o bien una concepción coexistencial de los derechos, que los considera delimitados por las exigencias de una sólida paridad humana previa a cualquier autodeterminación individual. El voluntarismo individualista lleva a considerar como "derechos" todas las manifestaciones de la libre autodeterminación de la voluntad que no lesionen expresamente el marco contractual de convivencia positivamente establecido para hacer posible la propia libertad. Los derechos serían meras pretensiones no prohibidas o -de utilizarse el término con particular contundencia- no susceptibles de prohibición. Desde esa lógica no resulta extraño que llegue a plantearse la posible existencia de un derecho a la muerte, de no contarse con fundamento para prohibir que cada cual pueda, en cualquier momento, determinar libremente si prefiere seguir vivo o morir. Si el Estado se arrogara la facultad de prohibirlo estaría incurriendo en abusivo "paternalismo", salvo que fundara su actuación en razones aún más dignas de atención que la libertad misma".

Pero, con la finalidad de negar ese presunto derecho a la muerte, el Tribunal Constitucional, en la ya citada Sentencia 120/1990, retoma pronunciamientos argüidos en un caso notablemente diverso como es el del aborto, pero en el que confluye igualmente la obligada protección de la vida humana, y, de manera idéntica que para el supuesto del no nacido, la vida de los presos en huelga de hambre justificaría la intervención protectora de derechos por el Estado "frente a los ataques de terceros, sin contar para ello con la voluntad de sus titulares e incluso cuando ni siquiera quepa hablar, en rigor, de titulares de ese derecho".

A raíz del caso de De Juana, sin embargo, el debate sobre la posibilidad de que algunas personas "utilicen" su vida y su muerte como un "producto a la carta" que puede consumirse en función de los fines que persigan quienes se creen amos y señores absolutos de su cuerpo y de su destino, se avivó más que nunca, pero el Tribunal Constitucional, en la mentada Sentencia 120/1990, ya había declarado la obligación del Estado, recurriendo incluso a medios coactivos, de proteger la vida de los reclusos declarados en huelga de hambre reivindicativa. Con ello, "no se degrada el derecho a la integridad física y moral de los reclusos, pues la restricción que al mismo constituye la asistencia médica se conecta casualmente con la preservación de bienes tutelados por la Constitución y, entre ellos, el de la vida que, en su dimensión objetiva, es un valor superior del ordenamiento jurídico constitucional y supuesto ontologico sin el que los restantes derechos no tendrían existencia posible". 
El Auto de la Audiencia Nacional que prorrogó en su día la prisión provisional a José Ignacio De Juana Chaos, pese a no citar a la conocida Sentencia, actuó en dos vertientes: primero, garantizando la vida del preso en huelga de hambre; $y$, segundo, impidiendo que pusiese su vida en riesgo con la finalidad de obtener ventajas penitenciarias.

En este punto y hora de estas reflexiones, podría conectarse la huelga de hambre de los internados en prisión con la de los enfermos internados en hospitales, huelga primordialmente ejercida con la finalidad última de conseguir la muerte propia. Como ejemplo, los recientes casos de Giovanni Nuvoli, en Italia y de Ellen Bergman, que fue mujer de Ingmar Bergman, en Suecia, y que vuelve a reabrir el tema de la eutanasia en países en los que está prohibida. Nuvoli mantuvo una huelga de hambre y sed infructuosa para que le desconectasen del respirador artificial que le mantenía con vida. Su esposa dijo "Ha sufrido como un perro". El caso de Ellen ha sido muy semejante, aunque llegó a escribir desgarradoras cartas al Gobierno y al Rey de Suecia para conseguir que los médicos le aplicasen el "Terminal sedering" (El sueño de la muerte), deseo que no se vio satisfecho, tras lo cual se declaró en huelga de hambre, siendo alimentada en el hospital por medio de una sonda, aunque terminó por morir.

El debate sobre la eutanasia también ha quedado abierto en nuestro país, sobre todo tras las muertes de Ramón Sampedro y de Inmaculada Echevarría, por lo que merece un tratamiento más profundo.

\section{EUTANASIA}

"Quien se ha convencido de esto, quien termina su vida, ya sea voluntariamente a través de la abstención de recibir alimentos o es puesto a dormir y encuentra salvación sin darse cuenta de la muerte. Contra su voluntad no se debe matar a nadie, se le debe prestar cuidados igual que a cualquier otro"

Tomás Moro

Utopía

"Dadme veneno para morir o sueños para vivir" Gunnar Ekelof 
El término eutanasia deriva del griego: eu -verdadero- y thánatos-muerte-. Es todo acto u omisión realizado por personal médico que ocasiona la muerte de un ser humano con el fin de evitarle sufrimientos insoportables o la prolongación artificial e inhumana de su vida. Actualmente se le distingue del término muerte digna que consiste en el otorgamiento de medidas médicas paliativas (que disminuyen el sufrimiento o lo hacen tolerable), de apoyo emocional y espiritual a los enfermos terminales.

La eutanasia no es algo nuevo y menos, como erróneamente se piensa, ligado al desarrollo de la medicina moderna. El sólo hecho de que el ser humano esté gravemente enfermo ha hecho que en las distintas sociedades la cuestión quede planteada. La eutanasia es un problema persistente en la historia de la humanidad en el que se enfrentan ideologías diversas.

La eutanasia no planteaba problemas morales en la antigua Grecia en donde la concepción de la vida era diferente. Una mala vida no era digna de ser vivida y por tanto ni el eugenismo, ni la eutanasia complicaban a las personas. Hipócrates representa una notable excepción ya que llegó a prohibir a los médicos la eutanasia activa y la ayuda para cometer suicidio.

Durante la Edad Media se produjeron cambios frente la muerte y al acto de morir. La eutanasia, el suicidio y el aborto son considerados como pecado, puesto que el hombre no puede disponer libremente sobre la vida, que le fue dada por Dios. El arte de la muerte (ars moriendi), en la cristiandad medieval, es parte del arte de la vida (ars vivendi); el que entiende la vida, también debe conocer la muerte. La muerte repentina (mors repentina et improvisa), deseo de tantas personas en la actualidad, se consideraba como una muerte mala ( $m a$ la mors). Se quiere estar plenamente consciente para despedirse de familiares y amigos y poder presentarse en el más allá con un claro conocimiento del fin de la vida.

La llegada de la modernidad rompe con el pensamiento medieval, la perspectiva cristiana deja de ser la única y se conocen y se discuten las ideas de la Antigüedad clásica. La juventud, la salud y la vida eterna pueden ser alcanzadas con el apoyo de la técnica, de las ciencias naturales y de la medicina.

Hay pensadores que justifican el término activo de la vida, condenado durante la Edad Media. El filósofo inglés Francis Bacon, en 1623, es el primero en retomar el antiguo nombre de eutanasia, y diferencia dos tipos: la eutanasia exterior, como término directo de la vida, y la eutanasia interior, como preparación espiritual para la muerte. Con esto, Bacon se refiere, por una parte, a la tradi- 
ción del ars moriendi como parte del ars vivendi, pero agrega a esta tradición algo que para la Edad Media era una posibilidad inimaginable: la muerte de un enfermo ayudado por el médico. Tomás Moro, quien también justifica el suicidio, en Utopía (1516), defiende la eutanasia activa sin usar este nombre.

Tanto para Moro como para Bacon es un requisito decisivo de la eutanasia activa el deseo del enfermo; contra la voluntad del enfermo o sin aclaración, la eutanasia no puede tener lugar.

Sin embargo, en la práctica, el comportamiento general de los médicos no siguió las ideas de los filósofos: rechazaron la eutanasia externa; justificaron la eutanasia pasiva y preconizaron la eutanasia interior.

Desde finales del siglo XIX, diversos enfoques, que señalan una nueva orientación, comienzan a exteriorizarse entre los médicos y pacientes, entre las personas y la sociedad. El darwinismo socialy la eugenesia son cuestiones que también comienzan a debatirse.

En numerosos países europeos se fundan, a comienzos del siglo XX, sociedades para la eutanasia y se promulgan informes para una legalización de la eutanasia activa. En las discusiones toman parte médicos, abogados, filósofos y teólogos.

La escasez económica en tiempos de la Primera Guerra Mundial sustenta la matanza de lisiados y enfermos mentales. El término eutanasia ha sido muchas veces separado de su sentido real, por ejemplo, los nazis hablaban de eutanasia para referirse a la eliminación de los minusválidos y débiles (Aktion T-4). En los Juicios de Nüremberg (1946-1947) se juzgó como ilegal e inmoral toda forma de eutanasia activa sin aclaración y consentimiento o en contra de la voluntad de los afectados.

Ya en el siglo XXI, concretamente en 2003, se confiscó en Australia al abogado Philip Nitschke una máquina cuando pretendía transportarla a los Estados Unidos. El aparato causaba la muerte a través de fuertes dosis de monóxido de carbono y fue de uso legal en el Territorio del Norte entre 1995 y 1997.

Sin embargo, no debemos olvidar que los relatados son hitos históricos producidos en el espacio público. Poco investigadas y mucho menos conocidas son las diferentes prácticas reales de las personas frente al acto de morir, a este respecto se sabe que hasta finales del siglo XIX en América del Sur exis- 
tía la persona del despenador, que era la encargada de hacer morir a los moribundos desahuciados a petición de los parientes.

En el presente, se sustentan diferentes opiniones sobre la eutanasia y son variadas las prácticas, médicas y las legalidades en los distintos países del mundo. Muchas prácticas como los hospicios u hogares, la medicina paliativa y los grupos de autoayuda, trabajan por la humanización en el trato con los moribundos y quieren contribuir a superar la distancia ente la vida y las prácticas médicas.

Pero actualmente existe mucha confusión en cuanto a la forma de calificar la eutanasia.

Prima en el contexto anglosajón la división en cuanto la eutanasia se lleve a cabo como una acción o como una omisión (dejar morir). Su traducción equivalente sería eutanasia activa y eutanasia pasiva respectivamente. Se ocupan en forma casi sinónima las calificaciones de positiva y negativa respectivamente.

Sin embargo, en el mundo hispanohablante se han introducido conceptos provenientes de la evaluación ética de la eutanasia y se la califica de directa o indirecta en tanto en cuanto exista o no la intención de provocar primariamente la muerte en las acciones que se realizan sobre el enfermo terminal.

En todo caso, se distingue la eutanasia del suicidio asistido, que consiste en proporcionarle al paciente los elementos necesarios para que él mismo dé fin a su sufrimiento.

Otros términos relacionados con la eutanasia son :

- Ortotanasia, que consiste en dejar morir a tiempo sin emplear medios desproporcionados y extraordinarios. Se ha sustituido en la terminología práctica por muerte digna, para centrar el concepto en la condición ("dignidad") del enfermo terminal y no en la voluntad de morir.

- Distanasia, que consiste en el "encarnizamiento o ensañamiento terapéutico", mediante el cual se le aplican al enfermo todo tipo de acciones "terapéuticas" con el fin de prolongar su vida a toda costa, llegando a la muerte en condiciones inhumanas.

Los argumentos en contra de la eutanasia inciden en la inviolabilidad de la vida humana, la defensa de su dignidad independientemente de las condi- 
ciones de vida o la voluntad del individuo implicado y las repercusiones sociales de desconfianza que podría conllevar la eutanasia.

La Asociación Médica Mundial considera contrarios a la ética tanto el suicidio con ayuda médica como la eutanasia, por lo que deben ser condenados por la profesión médica. En cambio recomienda los cuidados paliativos. Dice la Declaración adoptada en la 44 ${ }^{a}$ Asamblea Médica Mundial, celebrada en Marbella, España, en septiembre de 1992 y revisada en su redacción por la 170 ${ }^{\mathrm{a}}$ Sesión del Consejo, celebrada en Divonne-les-Baines, en Francia, en mayo de 2005:

"El suicidio con ayuda médica, como la eutanasia, es contrario a la ética y debe ser condenado por la profesión médica. Cuando el médico ayuda intencional y deliberadamente a la persona a poner fin a su vida, entonces el médico actúa contra la ética. Sin embargo, el derecho de rechazar tratamiento médico es un derecho básico del paciente y el médico actúa éticamente, incluso si al respetar ese deseo el paciente muere".

Y la Declaración adoptada por la 35 a Asamblea Médica Mundial, celebrada en Venecia, Italia, en octubre de 1983, y revisada por la Asamblea General de la Asociación Médica Mundial, celebrada en Pilanesaberg, Sudáfrica, en octubre de 2006:

"Cuando se abordan los problemas éticos asociados con la atención médica del término de la vida, se plantean inevitablemente interrogantes sobre la eutanasia y el suicidio con ayuda médica. La Asociación Médica Mundial condena como antiético tanto la eutanasia como el suicidio con ayuda médica. Se debe entender que la política de la AMM sobre estos temas se aplica plenamente al contexto de esta Declaración sobre Enfermedad Terminal".

Por su parte, la postura de las Iglesias cristianas, a nivel mundial, es mayoritariamente contraria a la eutanasia y al suicidio asistido, es el caso de la Iglesia Católica y de las Iglesias evangélicas y pentecostales. La postura del actual Papa Benedicto XVI quedó explícitamente recogida en una carta a varios eclesiásticos norteamericanos en el año 2004:

"No todos los asuntos morales tienen el mismo peso moral que el aborto y la eutanasia. Por ejemplo, si un católico discrepara con el Santo Padre sobre la aplicación de la pena de muerte o en la decisión de hacer la guerra, éste no sería considerado por esta razón indigno de presentarse a recibir la Sagrada Comunión. Aunque la Iglesia exhorta a las autoridades civiles a buscar la paz, y no la guerra, y a ejercer discreción y misericordia al castigar a criminales, aún sería lícito tomar las armas para repeler a un agre- 
sor o recurrir a la pena capital. Puede haber una legítima diversidad de opinión entre católicos respecto de ir a la guerra y aplicar la pena de muerte, pero no, sin embargo, respecto del aborto y la eutanasia".

Joseph Ratzinger

Carta al cardenal Theodore McCarrick, Arzobispo de Washington D.C.

Tercer Punto

Las Iglesias luteranas y metodistas en cambio, como asimismo la mayoría de las afiliadas a la Comunión Anglicana, se oponen en principio, pero dan espacio para la decisión individual caso por caso. Por otro lado, varias Iglesias han optado por no pronunciarse a este respecto y enfatizar el valor de la conciencia individual en cuestiones éticas, es el caso, entre otras, de las Iglesias católicas afiliadas a la Unión de Utrecht y de algunas Iglesias presbiterianas.

En España, tras los casos Sampedro y Echevarría, múltiples voces se han pronunciado en favor de la eutanasia, entre ellas las de la Asociación Derecho a Morir Dignamente, e, incluso, en el propio Congreso de los Diputados, un diputado de Los Verdes, adscrito al Grupo Socialista, Francisco Garrido, ha pretendido recientemente que se acordara la redacción de una enmienda a la reforma del Código Penal -por otras cuestiones-, tramitada en la Cámara Baja, a fin de que se abordara la despenalización de la eutanasia activa voluntaria, porque las "razones de inoportunidad" argumentadas por el Gobierno en su momento no existen y porque el caso de Inmaculada Echevarría ha evidenciado el "apoyo mayoritario" de la sociedad a este tipo de medidas.

Constituyen estos dos supuestos no resueltos de forma expresa en nuestra legislación positiva, pero en los que se ha tenido en cuenta por los Poderes públicos competentes la doctrina del Tribunal Constitucional Español, según ahora se verá.

Ramón Sampedro, tetrapléjico, murió por envenenamiento por cianuro, aunque fue él mismo quien ingirió el veneno que acabó con su vida, si bien fue ayudado por Ramona Maneiro. Caso de tan gran repercusión social que incluso fue llevado a la pantalla y los dos libros escritos por Sampedro resultaron un éxito de ventas. Éste, absolutamente convencido de sus propósitos, no dudó jamás en hablar con la prensa para conseguirlo.

El caso de Inmaculada Echevarría requiere un tratamiento a parte dado que el Consejo Consultivo de la Comunidad Autónoma de Andalucía se pro- 
nunció sobre la desconexión del aparato que la mantenía con vida tras estar postrada, sin posibilidad de recuperación alguna, en la cama de un hospital de Granada durante diez años, concretamente en el Hospital de San Rafael, perteneciente a la orden de San Juan de Dios, que se opuso públicamente a la desconexión de la paciente. Y mientras a Sampedro la Justicia le impidió suicidarse, en el caso de Echevarría, la Junta de Andalucía garantizó a los médicos que no habría causa penal. Inmaculada fue desconectada del aparato que la mantenía con vida el 13 de marzo de 2007, y, evidentemente, murió.

\section{CASO ECHEVARRÍA: DICTAMEN DEL CONSEJO CONSULTIVO DE ANDALUCIÁ}

"Lo único que pido es la eutanasia, no es justo vivir asi"

Inmaculada Echevarría

"Sin salud la vida no es vida: es un estado de tristeza y una imagen de la muerte". Rabelais

El Dictamen no 90/2007, de 27 de febrero de 2007 emitido por el Consejo Consultivo de Andalucía trae causa en la solicitud de la paciente, mediante escrito al equipo médico responsable de su atención, de la suspensión del tratamiento con ventilación mecánica que venía recibiendo durante los últimos diez años en el Hospital San Rafael de Granada, suspensión que conduciría con casi total probabilidad al fallecimiento de la paciente a causa de la avanzada, irreversible y mortal enfermedad que padecía. Inmaculada Echevarría asimismo había solicitado a la Consejera de Salud de la Junta de Andalucía que el Servicio Andaluz de Salud garantizase el ejercicio libre de su derecho a rechazar un tratamiento y que se respetase su voluntad de morir dignamente.

La Comisión Autonómica de Ética e Investigación Sanitarias de Andalucía emitió informe, a petición del equipo médico responsable y de la Consejera de Salud, en el que opinaba que la solicitud de Echevarría podía considerarse como un rechazo a un tratamiento que contenía una revocación del consentimiento previamente emitido para recibir tratamiento de soporte vital con ventilación mecánica, concluyendo, que una vez informada sobre la enfermedad, el tratamiento y sus alternativas, y, constatada la libertad, consistencia y estabilidad de la decisión tomada, no existían razones éticas que impidiesen cumplir la petición de su desconexión de la ventilación mecánica, aunque ello supusiese, con elevada probabilidad, la muerte de la paciente. 
Antes de entrar a analizar, dada su especial trascendencia en España, el dictamen en sí, merece destacarse la memoria justificativa que, con fecha 25 de enero de 2007, emite la Consejería de Salud sobre la necesidad de solicitar dictamen, destacando que:

"La difusión de este caso por los medios de comunicación social, ha generado un enorme interés, como puede constatarse por el gran número de reportajes, artículos periodísticos, editoriales o cartas al director aparecidos en los últimos meses, así como un intenso debate social, que se ha venido a sumar al que previamente habian desencadenado casos como el de Ramón Sampedro o Terry Schiavo entre otros.

(...) Entendemos que se trata de un asunto de especial trascendencia y repercusión, considerado tanto desde una perspectiva individual de la persona afectada, como desde una perspectiva general sobre las cuestiones que subyacen en este caso.

Desde el punto de vista individual, se trata de un caso de una mujer que padece una situación de sufrimiento insoportable y que no ha podido aún ejercer lo que entiende su derecho a rechazar el tratamiento de respiración asistida que se le viene aplicando desde hace 10 años, por las dudas existentes acerca de la licitud de la interrupción del citado tratamiento, dudas que los profesionales sanitarios responsables de la paciente necesitan resolver antes de tomar una decisión que tendría carácter irreversible. Estas dudas se extienden al papel de la autoridad sanitaria, que precisa disponer de un criterio inequívoco para, bien garantizar la efectividad de un derecho o, contrariamente, impedir la práctica de una actuación legalmente punible.

Desde el punto de vista social, cabe hacer las siguientes consideraciones:

Se trata de un tema de elevada sensibilidad social, pues afecta a derechos fundamentales como la libertad y la dignidad de la persona o la propia dignidad ante la muerte.

Incide sobre una cuestión considerada clave desde el punto de vista bioético y de la deontología médica: la autonomía del paciente en la toma de decisiones sobre su salud, concepto que aún no ha penetrado completamente en la práctica profesional sanitaria ni en el modelo de relación médico-enfermo predominante en nuestra sociedad.

El desarrollo científico y tecnológico de la medicina hace que casos como éste sean progresivamente más frecuentes, pues cada vez existen más dispositivos que permiten suplir funciones de órganos vitales y prolongar artificialmente la vida aún cuando no exista posibilidad de recuperación o el grado de sufrimiento sea inaceptable; lo que se ha denominado "encarnizamiento o ensañamiento terapéutico". 
Existe una notable confusión social, mediática e incluso profesional acerca de los conceptos de suicidio, eutanasia y limitación del esfuerzo terapéutico, que puede conducir a que no se hagan efectivos derechos de los pacientes reconocidos en nuestra legislación, a limitar indebidamente su aplicación, o a generar demandas judiciales por acción u omisión en estos supuestos.

Esta confusión genera una percepción de inseguridad jurídica en los profesionales sanitarios que se enfrentan a casos similares y, pese a disponer de claros criterios éticos o deontológicos, ni identifican una referencia clara sobre la legalidad de sus actuaciones, lo que genera incertidumbre en casos de gran trascendencia y elevada sensibilidad emocional y afectiva para el paciente y sus familiares.

Esta incertidumbre se extiende a las propias autoridades sanitarias ante la duda de cual sea la calificación jurídica que pueda darse a las actuaciones de los profesionales y a su propia posición de respaldo de las mismas.

Hay una gran repercusión social de todo lo que se refiere al proceso de la muerte y a los cuidados sanitarios y sociales alrededor de la misma, especialmente en los casos de enfermedades crónicas, invalidantes o que requieran de cuidados paliativos".

El dictamen se emite, por tanto, a la vista de las dudas que existen sobre dos cuestiones:

En primer lugar, la existencia de dudas sobre si el derecho a rechazar el tratamiento y el respeto a la autonomía del paciente puedan verse limitados o excepcionados en este caso por una posible colisión con otros elementos de nuestro ordenamiento jurídico.

Y, en segundo lugar, sobre las posibles consecuencias jurídicas de la actuación de los profesionales sanitarios en caso de proceder a la desconexión solicitada por la paciente, la que, probablemente fallecería.

Se solicitó, pues, por la Consejera de Salud que el Consejo Consultivo dictaminase sobre dos cuestiones:

Sobre si la solicitud de limitación del esfuerzo terapéutico y negativa al tratamiento con ventilación mecánica podía considerarse adecuada a derecho.

Y, para el supuesto de que la anterior consulta se sustanciase con un dictamen afirmativo, sobre si la actuación de los profesionales sanitarios procediendo a la desconexión del aparato de ventilación mecánica, una vez cum- 
plidos los requisitos establecidos por la Comisión Autonómica de Ética e Investigación Sanitarias de Andalucía, pudiera considerarse punible desde el punto de vista jurídico.

El Consejo Consultivo aclara con carácter previo que "la solicitud de dictamen justifica cumplidamente la especial trascendencia o repercusión del asunto, exigencia que deriva de lo previsto en los artículos 18 de la Ley del Consejo Consultivo y 8 de su Reglamento Orgánico. En éste se señala expresamente el deber de concretar estos extremos en el escrito de petición".

Dada la enorme repercusión del dictamen que se analiza, de entre sus Fundamentos Jurídicos cabría destacar lo siguiente:

El objetivo primordial del Consejo Consultivo en su el Fundamento Jurídico Primero es justificar la necesidad de la emisión del dictamen mismo:

"La Excma. Sra. Consejera de Salud solicita dictamen facultativo en relación con la petición formulada por doña Inmaculada Echevarria Ramírez para que le sea suspendido el tratamiento con ventilación mecánica, que viene recibiendo en los últimos diez años en el Hospital San Rafael de Granada.

Ante todo, cabe señalar que la solicitud de dictamen justifica cumplidamente la especial trascendencia o repercusión del asunto, exigencia que deriva de lo previsto en los artículos 18 de la Ley del Consejo Consultivo y 8 de su Reglamento Orgánico. En éste se señala expresamente el deber de concretar estos extremos en el escrito de petición.

Dificilmente cabe imaginar supuestos de mayor trascendencia que los que conciernan a la vida de las personas, y en este caso se trata de saber si resulta amparada por nuestro ordenamiento jurídico la solicitud planteada por doña Inmaculada Echevarría Ramirez, usuaria del servicio público sanitario andaluz, que, en caso de ser atendida, conducirá, con toda probabilidad derechamente a su fallecimiento.

La repercusión del asunto es igualmente notoria y no precisa de mayor explicitación. Trasciende incluso de la esfera estrictamente individual, ya que, según la solicitud de dictamen, han surgido dudas sobre las consecuencias jurídicas que, para los profesionales sanitarios concernidos, pueden derivarse de la estimación o rechazo de la solicitud de la paciente.

En el sentido expresado, la petición de dictamen subraya que una de las razones que impulsan a solicitarlo es el estado de duda generado "sobre si el derecho a rechazar el tratamiento y el respeto a la autonomía de la paciente pueden verse limitados o excep- 
cionados en este caso por una posible colisión con otros elementos de nuestro ordenamiento jurídico, y sobre las posibles consecuencias jurídicas de la actuación de los profesionales sanitarios en caso de proceder a la desconexión solicitada por la paciente con el previsible resultado del fallecimiento de la misma”.

Así pues, habiendo quedado justificada la trascendencia o repercusión del dictamen en el oficio de solicitud, en la memoria adjunta y en la restante documentación remitida por la Consejería de Salud, resulta procedente su emisión, de conformidad con lo dispuesto en los artículos 18 de la Ley del Consejo y 8 de su Reglamento Orgánico, en los términos y con el alcance que se concretan en el siguiente fundamento jurídico".

También destaca el Consultivo que su labor en ningún momento pretende convertirse en jurídica, ni tampoco desvirtuar los informes con anterioridad emitidos sobre cuestión tan controvertida, jurídica, técnico-sanitaria, ética, y filosóficamente; y que, en modo alguno, su decisión será vinculante:

"Antes de identificar las bases jurídicas que permiten dar respuesta a las cuestiones planteadas, es preciso realizar diversas precisiones sobre el sentido y alcance del presente dictamen. A este respecto, lo primero que hay que indicar es que este dictamen no es, ni podría serlo, un juicio del Consejo Consultivo sobre la validez o corrección jurídica del informe de la Comisión Autonómica de Ética e Investigación Sanitarias de Andalucía, ni sobre los informes emitidos por dos especialistas en Derecho Penal, que también figuran en el expediente.

En efecto, frente la confusión que se ha podido generar por el tratamiento de la noticia en algunos medios de comunicación, debe afirmarse que el dictamen de este Consejo no se presenta como segunda instancia consultiva, ni puede verse como una especie de pronunciamiento de validación o, en su caso, revisión o rechazo de las conclusiones alcanzadas por la Comisión Autonómica de Ética e Investigación Sanitarias de Andalucía. Asi pues, saliendo al paso de la confusión creada, hay que señalar que el dictamen no versa sobre el informe emitido por la citada Comisión, aunque éste resulte un antecedente valioso, entre otros que obran en el expediente, para dar respuesta a las dos cuestiones suscitadas.

El papel del Consejo y la naturaleza de la propia función consultiva no experimentan en estos supuestos una transubstanciación por el carácter facultativo de la consulta y la presencia de aspectos éticos, filosóficos, deontológicos y técnico-sanitarios que no suelen concurrir en otros dictámenes, o al menos no lo hacen con la misma intensidad.

Al igual que sucede con los dictámenes preceptivos, la función que ejerce el Consejo Consultivo al dar respuesta a las consultas facultativas no es otra que la de velar por la 
observancia de la Constitución, el Estatuto de Autonomía para Andalucía y el resto del ordenamiento jurídico (arts. 1 de la Ley del Consejo y 2 de su Reglamento Orgánico).

Esta caracterización legal de la función que está llamado a ejercer el Consejo Consultivo lleva a excluir otro tipo de valoraciones o consideraciones, que con toda legitimidad y solvencia pueden efectuar otros órganos especializados, especialmente capacitados para hacerlas, dado su cometido y composición.

Tal es precisamente lo que sucede con la Comisión Autonómica de Investigación y Ética Sanitarias o con las Comisiones de Ética e Investigación Sanitarias de los centros hospitalarios, de las que se puede esperar la asistencia y el asesoramiento en bioética y la resolución de cuestiones de carácter técnico y científico, en los términos previstos en el Decreto 232/2002, de 17 de septiembre, por el que se regulan los órganos de Ética e Investigación Sanitarias y los de Ensayos Clínicos en Andalucia; Comisiones cuya intervención en este terreno viene respaldada por la especialización y conocimientos de sus miembros en las materias relacionadas con la ética sanitaria y la praxis médica o con la investigación en esta rama de la ciencia.

Por consiguiente, el dictamen queda constreñido al análisis de las cuestiones estrictamente jurídicas del supuesto, sin que el pronunciamiento de este Consejo deba ir más allá de la respuesta concreta a las cuestiones que se le solicitan, a saber:

"1. Si la solicitud de limitación del esfuerzo terapéutico y negativa al tratamiento con ventilación mecánica, efectuada por la paciente doña Inmaculada Echevarria Ramírez puede considerarse adecuada a derecho.

2. En el supuesto de que la anterior consulta se sustancie con un dictamen afirmativo, si la actuación de los profesionales sanitarios procediendo a la desconexión del aparato de ventilación mecánica, una vez cumplidos los requisitos establecidos por la Comisión Autonómica de Ética e Investigación Sanitarias, puede considerarse punible desde el punto de vista jurídico".

Se trata, como se ve, de cuestiones muy precisas y a ellas debe atenerse este Consejo, en lógica congruencia con la concepción de la función consultiva que le compete en un dictamen de esta naturaleza, que no viene ordenado preceptivamente ni resulta vinculante.

En relación con esta última precisión, y frente a los equívocos que pudieran resultar de una deficiente o defectuosa información, hay que puntualizar no sólo que la consulta no es preceptiva, por no venir legalmente establecida, sino que tampoco es vinculante (art. 4 de la Ley del Consejo), de modo que el pronunciamiento de este Órgano no puede ser calificado ni presentado como trámite determinante y en cierto modo codeciso- 
rio, sino como una opinión en Derecho sobre un tema en el que es difícil prever el entendimiento o interpretación que corresponde realizar a otras instancias en sus respectivas esferas de competencias.

Esto dicho, el Consejo Consultivo entiende que la solución a las cuestiones planteadas pasa por el examen de la jurisprudencia y la interpretación de las normas que regulan la autonomía de los pacientes y el consentimiento por éstos de los tratamientos médicos, así como por la regulación que efectúa el Código Penal para la protección de la vida y de la integridad física y moral".

Sentado lo anterior, el dictamen procede a hacer un exhaustivo repaso al más alto nivel por todos los derechos involucrados en este supuesto, desde la Constitución Española, pasando por otras Constituciones europeas, hasta las más famosas Cartas de Derechos del ser humano:

"Comenzamos por recordar, que el artículo 15 de la Constitución dispone que todos tienen derecho a la vida y a la integridad física y moral, sin que, en ningún caso, puedan ser sometidos a tortura ni a penas o tratos inhumanos o degradantes. Acto seguido, el precepto establece que queda abolida la pena de muerte, salvo lo que puedan disponer las leyes penales militares para tiempos de guerra.

Siendo derecho matriz de todos los demás, se explica que el reconocimiento del derecho a la vida se produzca en el primer artículo de la sección primera del capítulo II del título 1 de la Constitución (arts. 15 a 29), junto con los derechos que gozan del grado más elevado de protección, como se evidencia en los instrumentos de tutela, fuentes de regulación y cauce agravado de reforma constitucional, artículos todos ellos que indudablemente les conciernen (arts. 53.2, 81 y $168 \mathrm{CE}$ ).

La propia Constitución Española establece en su artículo 10.1 que la dignidad de la persona, los derechos inviolables que le son inherentes, el libre desarrollo de la personalidad, el respeto a la ley y a los derechos de los demás son fundamentos del orden político y de la paz social.

La amplia casuística abarcada por la jurisprudencia constitucional en esta materia, sobre todo en el proceso de amparo, ha llevado a interpretar el derecho a la vida conjuntamente con otros valores y derechos constitucionales, dando respuesta a los conflictos alegados por los recurrentes en cada caso. En este sentido se deja apuntada la relevancia que en diversos supuestos se ha atribuido a la consideración de la libertad como valor superior del ordenamiento juridico (art. 1.1) y como derecho fundamental (art. $17.1 \mathrm{CE}$ ); a la libertad ideológica y religiosa (art. $16 \mathrm{CE}$ ); al derecho a la intimidad (art. 18) y al derecho a la protección de la salud que ha de ser garantizado por los 
poderes públicos (art. $43 \mathrm{CE}$ ). En casos concernientes a personas que cumplen condena en instituciones penitenciarias, se ha ponderado también la significación de la existencia de una relación especial de sujeción, como se verá después, a la luz del artículo 25.2 de la Constitución.

Ciertamente que la presencia del derecho a la vida en las Constituciones no siempre se ha considerado necesaria, por ser presupuesto de todos los demás derechos del ser humano, y considerarse, por tanto, inalienable e inviolable. Sin embargo, dicha presencia se explica ante acontecimientos que han puesto de relieve las atrocidades cometidas con desprecio del derecho a la vida y por la necesidad de reflejar también una concepción moderna de dicho derecho, unida a la protección de la integridad fisica y moral del individuo, lo que se traduce no sólo en el establecimiento de normas de contenido y naturaleza negativos o represivos y medios para la defensa de dicho derecho, sino también en deberes positivos que incumben a todos los poderes públicos para promover y proteger en sus diferentes facetas el derecho a la vida, como pieza fundante o basilar que es del ordenamiento jurídico.

En el mismo sentido, además de las referencias a la Constitución Española, se podrian citar otros textos constitucionales (v.gr.: arts. 2 y 102 de la Ley Fundamental de la República Federal de Alemania, 13 y 27 de la Constitución italiana y 25 y 26 de la Constitución de Portugal, entre otros).

En este contexto, hay que tener igualmente presente que, según el artículo 10.2 de la Constitución Española, las normas relativas a los derechos fundamentales y a las libertades que la Constitución reconoce se interpretarán de conformidad con la Declaración Universal de Derechos Humanos y los tratados y acuerdos internacionales sobre las mismas materias ratificados por España.

Sobre la anterior premisa, hay que traer a colación la Declaración Universal de los Derechos Humanos de 1948, que reconoce en su artículo 3 el derecho a la vida, a la libertad y a la seguridad. Además, en su artículo 5 dispone que nadie será sometido a torturas ni a penas o tratos crueles, inhumanos o degradantes.

El Pacto Internacional de derechos civiles y políticos de 1966 reconoce también en su artículo 6.1 que el derecho a la vida es inherente a la persona humana y ha de estar protegido por la ley, sin que nadie pueda ser privado de la vida arbitrariamente. El artículo 7 de dicho Pacto establece que nadie será sometido a torturas ni a penas o tratos crueles, inhumanos o degradantes y que, en particular, nadie será sometido sin su libre consentimiento a experimentos médicos o científicos.

Por su parte, el Convenio para la Protección de los Derechos Humanos y de las Libertades Fundamentales de 1950 dispone en su artículo 2.1 que el derecho de toda per- 
sona a la vida está protegido por la Ley, sin que nadie pueda ser privado de su vida intencionadamente, salvo en ejecución de una condena que imponga pena capital dictada por el tribunal al reo de un delito para el que la ley establece esa pena. Como complemento de lo anterior, en su artículo 3 se establece que nadie podrá ser sometido a tortura ni a penas o tratos inhumanos o degradantes. A su vez, el artículo 8 se refiere al derecho de toda persona al respeto de su vida privada y familiar, sin que se permita injerencia de la autoridad pública en el ejercicio de este derecho, salvo que ésta esté prevista por la ley y constituya una medida que, en una sociedad democrática, sea necesaria para la protección de los bienes jurídicos que se enumeran en la norma, entre lo que se encuentran la protección de la salud o de la moral, o la protección de los derechos y las libertades de los demás.

Existen otros instrumentos internacionales específicos para la protección de la vida y la prevención de la tortura y tratos inhumanos o degradantes; prevención y sanción del genocidio; imprescriptibilidad de los crímenes de guerra, etc., pero el Convenio que más directamente atañe a las cuestiones objeto de dictamen es, sin duda, el del Consejo de Europa para la protección de los derechos humanos y la dignidad del ser humano respecto de las aplicaciones de la biología y la medicina, suscrito en Oviedo el 4 de abril de 1997, y vigente en España, desde el 1 de enero de 2000. De él nos ocuparemos en el siguiente fundamento jurídico".

Posteriormente da cuenta el dictamen de la interesante jurisprudencia del Tribunal Constitucional sobre el Derecho a la vida:

"En congruencia con el significado del derecho a la vida en nuestra Carta Magna y en las Declaraciones de Derechos y Convenios citados, la jurisprudencia del Tribunal Constitucional ha considerado que la vida protegida por el artículo 15 de la Constitución, en su doble significación física y moral, es un valor superior del ordenamiento jurídico constitucional -la vida humana-y "constituye el derecho fundamental esencial y troncal en cuanto es el supuesto ontológico sin el que los restantes derechos no tendrían existencía posible". Derecho a la vida que el Tribunal concibe como indisolublemente relacionado con el valor juridico fundamental de la dignidad de la persona, reconocido en el artículo 10 como germen o núcleo de unos derechos "que le son inherentes".

La relevancia y la significación superior de ambos se deduce, como subraya el Tribunal Constitucional, de la ubicación dentro de la Constitución, que viene a demostrar que "dentro del sistema constitucional son considerados como el punto de arranque, como el prius lógico y ontológico para la existencia y especificación de los demás derechos" (STC 53/1985, de 11 de abril, FJ 3, y en el mismo sentido SSTC 120/1990, de 28 de junio, FJ 10, y 154/2002, de 18 de julio). 
Al hilo de las consideraciones anteriores, el Tribunal Constitucional subraya que los derechos fundamentales no incluyen solamente derechos subjetivos de defensa de los individuos frente al Estado, y garantías institucionales, sino también deberes positivos por parte de éste (vid, al respecto arte. 9.2, 17.4, 18.1 y 4, 20.3 y 27 de la Constitución). Señala el Tribunal que "los derechos fundamentales son los componentes estructurales básicos, tanto del conjunto del orden jurídico objetivo como de cada una de las ramas que lo integran, en razón de que son la expresión jurídica de un sistema de valores, que, por decisión del constituyente, ha de informar el conjunto de la organización jurídica y política; son, en fin, como dice el artículo 10 de la Constitución, el "fundamento del orden jurídico y de la paz social".

Partiendo de estas premisas fundamentales, el Tribunal Constitucional ha analizado el artículo 15 de la Constitución en una larga lista de sentencias que operan en diferentes planos. Así, junto a las que después se referirán, cabe citar las siguientes: 75/1984, de 27 de junio (punición de aborto realizado en el extranjero); 65/1986, de 3 de junio, y 2/1987, de 21 de enero (aislamiento de presos en celdas); 89/1987, de 3 de junio (restricción de las relaciones sexuales de los reclusos); 7/1994, de 17 de enero (sometimiento a investigación de paternidad); 215/1994, de 14 de julio (posibilidad de esterilización de incapaces); 57/1994, de 28 de febrero (registros corporales a reclusos); 37/1989, de 15 de febrero, 207/1996, de 16 de diciembre, y 234/1997, de 18 de diciembre (intervenciones corporales en procesos penales); 116/1999, de 17 de junio (recurso de inconstitucionalidad frente a la Ley de técnicas de reproducción asistida); 119/2001, de 24 de mayo (posibilidad de que el ruido pueda llegar a infringir los derechos a la vida y a la integridad física y moral) ; 181/2000, de 29 de junio, 21/2001, de 29 de enero, 223/2001, de 5 de noviembre, 31/2003, de 13 de febrero, 42/2003, de 3 de marzo, 134/2003, de 30 de junio, 156/2003, de 15 de septiembre, 105/2004, de 28 de junio, 222/2004, de 29 de noviembre, 230/2005 y 231/2005, de 26 de septiembre, y 5/2006, de 16 de enero (baremos de indemnización por daños sufridos en accidentes de tráfico en relación con la integridad física de las víctimas); 221/2002 (derecho a la integridad moral de un menor en los procedimientos sobre guarda y custodia de niños en situación de desamparo); 220/2005, de 12 de septiembre (denegación administrativa de prórroga de baja por incapacidad laboral temporal y posible riesgo palmario y grave para la salud de la afectada).

Cabe advertir que el Tribunal Constitucional no ha abordado directamente una problemática como la que ahora centra este dictamen. Si cabe, en cambio, referir que, en julio de 1996, fue presentado ante el Tribunal Constitucional un recurso de amparo frente al auto de la Audiencia Provincial de A Coruña, de 19 de noviembre de 1996, en el que se instaba al Tribunal Constitucional (tras remodelación en el suplico de la demanda) a declarar que el órgano judicial debió haber reconocido "el derecho del actor a 
que su médico de cabecera quedase autorizado a que le suministrase los medicamentos necesarios para evitar el dolor, la angustia y la ansiedad que el estado en que vivía le producía, sin que ello, en ningún caso, pudiera haber sido considerado, desde el punto de vista penal, como ayuda al suicidio, delito o falta de clase alguna, ya que el actor asumió plenamente, por su parte, el riesgo de que tal medicación podía suponer y poder así, llegado el caso -como llegó- morir dignamente".

Sin embargo, en el auto 242/1998, de 11 de noviembre, el Tribunal acuerda denegar la solicitud de sucesión procesal formulada por la heredera del demandante y declarar extinguido, por fallecimiento de aquél, el referido proceso constitucional de amparo. Entre los razonamientos empleados por el Tribunal para dictar el referido auto, se señala que el invocado derecho a morir dignamente, mediante la intervención no punible de terceros en la muerte eutanásica, que fue el derecho cuyo amparo se pretendió, no permite la sucesión procesal, al no contemplarlo el legislador y no producirse efectos que trasciendan del sujeto titular y se extiendan de manera refleja al círculo familiar o de sus más próximos allegados. Por el contrario, precisa el Tribunal Constitucional, estamos ante una pretensión de carácter personalísimo e indisolublemente vinculada a quien la ejercita, como "un acto de voluntad que sólo a él afecta» (STC 120/1990, FJ 7 y STC 137/1990, FJ 5)".

Pero, por su mayor conexión con el presente dictamen, puede identificarse un conjunto de sentencias del Tribunal Constitucional que aportan elementos de juicio valiosos sobre la asistencia sanitaria y el consentimiento de los afectados a la luz del artículo 15 de la Constitución, a estos efectos, vienen a analizar una sentencia ya referida en este estudio cuando se abordaba la controvertida cuestión de los terroristas en huelga de hambre, la famosa sentencia del Tribunal Constitucional 120/1990, de 28 de junio:

“(...) hay que recordar la doctrina sentada por la sentencia del Tribunal Constitucional 120/1990, de 28 de junio, en relación con el amparo formulado por reclusos del GRAPO en huelga de hambre que combaten la resolución judicial que reconoce el derecho-deber de la Administración Penitenciaria de suministrarles la asistencia médica necesaria, conforme a criterios de la ciencia médica, aun en contra de su voluntad, siempre que la vida de los mismos corriere peligro y asi lo hubieren determinado los informes médicos.

La sentencia 120/1990 introduce importantes consideraciones que, mutatis mutandis, han de ser tenidas en cuenta, por cuanto suponen precisiones muy relevantes en relación a lo que el artículo 15 de la Constitución representa con referencia a las posiciones contrapuestas de las partes en relación con la asistencia médica coactiva y la disponibilidad del paciente sobre la propia vida. 
En efecto, la relevancia de la sentencia 120/1990 para el presente dictamen estriba en que el objeto del recurso de amparo que resuelve examina la compatibilidad de la resolución judicial que ordena la asistencia médica forzosa en las circunstancias dichas con los artículos 1.1, 9.2, 10.1, 15, 16.1, 17.1, 18.1, 24.1 y 25.2 de la Constitución.

Antes de abordar el conflicto que los recurrentes aducen entre tales derechos y la asistencia médica coactiva, el Tribunal Constitucional establece varias precisiones sobre el significado constitucional del derecho a la vida. La primera, siguiendo la doctrina de la sentencia 53/1985, para recordar que este derecho fundamental, como fundamento objetivo del ordenamiento, impone a los poderes públicos y en especial al legislador, el deber de adoptar las medidas necesarias para proteger la vida e integridad física frente a los ataques de terceros, sin contar para ello con la voluntad de sus titulares e incluso cuando ni siquiera quepa hablar, en rigor, de titulares de ese derecho. Por ello señala el Tribunal que el derecho a la vida tiene "un contenido de protección positiva que impide configurarlo como un derecho de libertad que incluya el derecho a la propia muerte". (FJ 7).

Sin perjuicio de lo anterior, reconoce el Tribunal que dicha interpretación no impi$d e$, sin embargo, reconocer que, siendo la vida "un bien de la persona que se integre en el círculo de su libertad", pueda aquélla fácticamente disponer sobre su propia muerte, "pero esa disposición constituye una manifestación del agere licere, en cuanto que la privación de la vida propia o la aceptación de la propia muerte es un acto que la ley no prohíbe y no, en ningún modo, un derecho subjetivo que implique la posibilidad de movilizar el apoyo del poder público para vencer la resistencia que se oponga a la voluntad de morir, ni, mucho menos, un derecho subjetivo de carácter fundamental en el que esa posibilidad se extienda incluso frente a la resistencia del legislador, que no puede reducir el contenido esencial del derecho". En esta línea, concluye el Tribunal Constitucional que "no es posible admitir que la Constitución garantice en su artículo 15 el derecho a la propia muerte y, por consiguiente, carece de apoyo constitucional la pretensión de que la asistencia médica coactiva es contraria a eses derecho constitucionalmente inexistente" (ibidem).

En el mismo fundamento jurídico, y reafirmando que la decisión de arrostrar la propia muerte no es un derecho sino simplemente manifestación de libertad genérica, la sentencia 120 /1990 precisa lo siguiente:

“(...) es oportuno señalar la relevancia jurídica que tiene la finalidad que persigue el acto de libertad de oponerse a la asistencia médica, puesto que no es lo mismo usar de la libertad para conseguir fines lícitos que hacerlo con objetivos no amparados por la Ley, $y$, en tal sentido, una cosa es la decisión de quien asume el riesgo de morir en un acto de voluntad que sólo a él afecta, en cuyo caso podría sostenerse la ilicitud de la asistencia médica obligatoria o de cualquier otro impedimento a la realización de esa voluntad, y 
cosa bien distinta es la decisión de quienes, hallándose en el seno de una relación especial penitenciaria, arriesgan su vida con el fin de conseguir que la Administración deje de ejercer o ejerza de distinta forma potestades que le confiere el ordenamiento jurídico; pues, en este caso, la negativa a recibir asistencia médica sitúa al Estado, en forma arbitraria, ante el injusto de modificar una decisión, que es legítima mientras no sea judicialmente anulada, o contemplar pasivamente la muerte de personas que están bajo su custodia y cuya vida está legalmente obligado a preservar y proteger".

Como recuerda el dictamen, la sentencia subraya la relevancia de la existencia de una relación especial de sujeción y encuentra justificado que el Estado y, en concreto, la Administración penitenciaria cumpla un papel activo de protección de la vida de los reclusos, en la medida en que se trata de "personas que están bajo su custodia y cuya vida está legalmente obligado a preservar y proteger".

Dando respuesta a la alegada colisión de la asistencia médica forzosa con el derecho a la integridad física y moral -dice-, también reconocido por el artículo 15 de la Constitución, el Tribunal Constitucional precisa que esta dimensión del artículo 15 protege "la inviolabilidad de la persona, no sólo contra ataques dirigidos a lesionar su cuerpo o espíritu, sino también contra toda clase de intervención en esos bienes que carezca del consentimiento de su titular". Por ello, sigue manifestando el Tribunal, "este derecho constitucional resultará afectado cuando se imponga a una persona asistencia médica en contra de su voluntad, que puede venir determinada por los más variados móviles y no sólo por el de morir y, por consiguiente, esa asistencia médica coactiva constituirá limitación vulneradora del derecho fundamental, a no ser que tenga justificación constitucional” (FJ 8).

Más adelante -continua el dictamen en su interpretación-, rechaza el Tribunal que la autorización de la intervención médica forzosa de los reclusos en peligro de muerte, aun en contra su voluntad, suponga una violación de su derecho a la integridad física y moral o pueda calificarse de tortura o de trato inhumano o degradante, con el sentido que esos términos revisten en el artículo 15 de la Constitución, pues aquélla, "en sí misma, no está ordenada a infligir padecimientos físicos o psíquicos ni a provocar daños en la integridad de quien sea sometido a ellos, sino a evitar, mientras médicamente sea posible, los efectos irreversibles de la inanición voluntaria, sirviendo, en su caso, de paliativo o lenitivo de su nocividad para el organismo". Tampoco el empleo de la coerción para efectuar dicha intervención comportaría la lesión aducida, al considerar el Tribunal que "no es la coercitividad de trato más allá de lo proporcionado, sino su desmedida severidad, su innecesario rigor y su carácter vejatorio lo que a los efectos de la prohibición constitucional resulta relevante" (FJ 9). 
"En suma, -concluye- para el Tribunal Constitucional, la asistencia médica obligatoria, autorizada por la resolución judicial objeto del recurso de amparo, no vulnera ninguno de los derechos fundamentales invocados por los demandantes, ni en sí misma, ni en la forma y alcance con que ha sido autorizada, constituyendo tan sólo una limitación del derecho a la integridad física y moral garantizada por el artículo 15 de la Constitución, y unida ineludiblemente a ella una restricción a la libertad fisica, que vienen justificadas en la necesidad de preservar el bien de la vida humana, constitucionalmente protegido, y que se realiza mediante un ponderado juicio de proporcionalidad, en cuanto entraña el minimo sacrificio del derecho que exige la situación en que se hallan aquéllos respecto de los cuales se autoriza” (FJ 12).

Analiza igualmente el Consejo Consultivo la misma doctrina que se vuelve a reiterar en la también mentada sentencia del Tribunal Constitucional 137/1990, de 19 de julio, en la que se deniega el amparo solicitado, "reiterándose que la asistencia médica a reclusos del GRAPO en huelga de hambre, autorizada por la resolución judicial, no vulnera ninguno de los derechos fundamentales invocados por los demandantes, por constituir tan sólo una limitación del derecho a la integridad física y moral garantizada por el artículo 15 de la Constitución. Con la argumentación ya conocida, la sentencia 137/1990 considera justificado el tratamiento terapéutico coercitivo (alimentación forzosa) ante lo que califica como "peligro de muerte", o "riesgo serio" para la vida del recluso (FJ 8), y ello con el objetivo de "evitar, mientras médicamente sea posible, los efectos irreversibles de la inanición voluntaria” (FJ 9), justificándose la asistencia coactiva por "la necesidad de preservar el bien de la vida humana constitucionalmente protegido" (FJ 10), y siempre condicionando tal actuación a la existencia del grave y cierto peligro de muerte o de entrar en una situación irreversible, según las indicaciones médicas.

En el fundamento jurídico noveno de la sentencia 137/1990, el Tribunal Constitucional reitera que no es tampoco pertinente incluir en la esfera del artículo 17 de la Constitución, como los recurrentes pretenden, la libertad de rechazar tratamientos terapéuticos, en cuanto manifestación de la libre autodeterminación de la persona. En este sentido se argumenta, al igual que se hizo en la sentencia 120/1990 (y antes en las SSTC 126/1987, 22 y 112/1988 y 61/1990, entre otras) que la libertad personal protegida por dicho precepto es la "libertad física", sin que pueda cobijarse en el mismo una libertad general de actuación o una libertad general de autodeterminación individual, pues esta clase de libertad, que es un valor superior del ordenamiento jurídico -art. 1.1 CE-, sólo tiene la protección del recurso de amparo en aquellas concretas manifestaciones a las que la Constitución les concede la categoría de derechos fundamentales incluidos en el capitulo segundo de su título 1, como son las libertades a que se refieren el propio artículo 17.1 y los artículos 16.1, 18.1, 19 y 20, entre otros". 
La sentencia del Tribunal Constitucional 11/1991, de 17 de enero, también referida a una huelga de hambre de un recluso del GRAPO, es asimismo objeto de reflexión por el Consejo Consultivo. En ella el Tribunal analiza una pretensión de signo inverso a la que sostenían los demandantes en los recursos de amparo resueltos por las sentencias 120 y 137/1990. "Es el Fiscal, desde un planteamiento que entiende amparado en la doctrina sentada en dichas sentencias, el que solicita la nulidad de una resolución judicial, al estimar que ésta resulta insuficiente desde la perspectiva del deber positivo de protección del derecho a la vida, al haber denegado la alimentación forzosa defendida por la Administración Penitenciaria en los siguientes términos: " ${ }^{\circ}$ Respetar la libre y consciente voluntad del interno.., de no ser asistido médicamente ni alimentado forzadamente hasta que, perdida su consciencia o por tomar una decisión contraria a la actual, precise que se le presten los auxilios médicos necesarios para la salvaguarda de su integridad física y moral..."

La sentencia del Tribunal Constitucional 11/1991 declara no haber lugar al amparo solicitado, al considerar que "establecer el momento y la forma en que haya de procederse de manera coactiva para evitar riesgos intolerables para la vida del interno no es algo que corresponda hacer a este Tribunal, dado que ello supondría una clara injerencia en la competencia propia de la Administración Penitenciaria..."

En el sentido indicado, según el Consejo, la sentencia argumenta que en la resolución judicial impugnada sólo existen algunos matices sobre el momento en que se permite la alimentación forzosa y la asistencia médica de los ayunantes. Por ello, se establece la siguiente conclusión:

“(...) si se declaró compatible con la Constitución y con los derechos fundamentales entonces invocados que la alimentación forzosa tuviera lugar una vez que la vida de los reclusos en huelga de hambre corriera grave peligro, lo que se determinaría previo los oportunos informes médicos y en la forma que el Juez de Vigilancia Penitenciaria estableciera, no puede extraerse de esta declaración que la fijación del momento a partir del cual se permita la alimentación forzosa, haya de sujetarse necesariamente al mismo momento en todos los casos en que resulte aplicable el art. 3.4 LOGP. Y no es lo mismo, naturalmente, reconocer, como se hizo en las SSTC 120/1990 y 137/1990, que no es incompatible con la Constitución el derecho-deber que con base en el art. 3.4 LOGP ejerció en aquellos casos la Administración Penitenciaria que, elevando a rango constitucional las atribuciones que el citado precepto otorga a la Administración, convertirlos en derechos susceptibles de amparo constitucional.” (FJ 4).

Resulta, asimismo, de interés para dictaminar por el Consejo Consultivo, a la vista de su relación con la problemática jurídica que pueden suscitar el rechazo de tratamiento o medidas terapéuticas, la sentencia del Tribunal Cons- 
titucional 48/1996, de 25 de marzo, en un supuesto donde se cuestiona la resolución judicial denegatoria de la excarcelación del recluso recurrente por una dolencia coronaria grave e incurable:

"Al dar respuesta a la alegación del demandante de amparo sobre la lesión de su derecho a la vida, subraya el Tribunal que éste, como soporte existencial de cualesquiera otros derechos y primero, por ello, en el catálogo de los fundamentales, tiene un carácter absoluto y está entre aquellos que no pueden verse limitados por pronunciamiento judicial alguno ni por ninguna pena. Y en relación con lo anterior, añade la sentencia (FJ 2) que la Administración penitenciaria no sólo ha de cumplir el mandato constitucional con una mera inhibición respetuosa, negativa pues, sino que le es exigible una función activa para el cuidado de la vida, la integridad corporal y, en suma, la salud de los hombres y mujeres separados de la sociedad por medio de la privación de su libertad (SSTC 120/90, 137/90 y 11/91). Con todo, matiza el Tribunal Constitucional que la relación de sujeción especial entre el recluso y la Administración penitenciaria que hace nacer la condena judicial a una pena de prisión, permite limitar ciertos derechos fundamentales por razón del mismo condicionamiento material de la libertad, pero a la vez impone que se proteja y facilite el ejercicio de los demás que no resulten necesariamente limitados (STC 2/87)".

En la sentencia que venimos comentando, las consideraciones de mayor interés en relación con el dictamen que nos ocupa son las que se realizan al dar respuesta a una de las alegaciones que habían sido utilizadas para denegar la libertad condicional: "En la mano del interno -afirmó la resolución judicial combatida- está aliviar su enfermedad, optando por someterse a una intervención quirúrgica, la cual podrá ser realizada por un médico de la confianza del propio interno o de sus familiares, con la adopción de las correspondientes medidas cautelares personales". Frente a ella, el Tribunal Constitucional opone que "el derecho a la integridad fisica y moral no consiente que se imponga a alguien una asistencia médica en contra de su voluntad, cualesquiera que fueren los motivos de esa negativa..." (STC 120/90). En esta dirección, subraya el Tribunal que "la decisión de permitir una agresión de esa envergadura aunque con finalidad curativa es personalisima y libérrima, formando parte inescindible de la protección de la salud como expresión del derecho a la vida".

Culminan el conjunto de sentencias cuyo análisis se ha considerado de interés en el presente supuesto las sentencias 166/1996, de 28 de octubre y 154/2002, de 18 de julio, sobre trasfusiones de sangre a testigos de Jehová:

En la primera de ellas, la sentencia 166/1996, de 28 de octubre, lo que se plantea en realidad es si existe lesión de derechos fundamentales por la denegación de reintegro de los gastos producidos para el recurrente, que tuvo 
que acudir a la medicina privada al no serle garantizado por los servicios de la Seguridad Social un tratamiento, conforme a sus creencias religiosas, que excluyera en todo caso la transfusión de sangre en la intervención quirúrgica que se le tenía que practicar. En su segundo fundamento jurídico, según el Consejo, «recuerda el Tribunal que anteriormente ha declarado que la libertad religiosa, entendida como un derecho subjetivo de carácter fundamental, se concreta en el reconocimiento de un ámbito de libertad y de una esfera de "agere licere" del individuo, es decir, reconoce el derecho de los ciudadanos a actuar en este campo con plena inmunidad de coacción del Estado y de cualesquiera grupos sociales (STC 24/82). Y ha declarado también en relación con un problema similar al aqui planteado, que una asistencia médica coactiva constituiría una limitación vulneradora del derecho fundamental, a no ser que tuviera justificación constitucional (STC 120/90)».

Pero es la sentencia 154/2002 la que presenta mayor interés, al tratarse de un supuesto en que es un menor quien se niega, como también sus padres (aunque éstos acabaran conformándose con la intervención judicial), a la realización de una transfusión de sangre, aduciendo motivos religiosos.

Los recurrentes basan sus alegaciones en la afirmación contenida en la sentencia del Tribunal Constitucional 120/1990 en relación con la asistencia médica coactiva, al considerarla "limitación vulneradora del derecho fundamental a no ser que tenga justificación constitucional", apoyándose en una cita doctrinal en la que se sostiene que sólo la vida compatible con la libertad es objeto de reconocimiento constitucional.

También aquí -dice el dictamen- "interesa destacar la posición del Ministerio Fiscal, al encarar la alegación de los recurrentes en el sentido de que la condena se pronuncia sin tener en cuenta que la conducta omisiva responde a la incompatibilidad de la acción exigida -transfundir sangre- con las creencias religiosas que profesan los recurrentes. A este respecto afirma el Ministerio Fiscal que, ante un eventual conflicto entre los derechos a la vida y a la libertad religiosa, únicamente cabe dar respuesta en cada caso concreto, pues no podría ser ésta la misma en el caso de personas mayores de edad y con plena capacidad de decisión que en el de un menor sobre el que existe vigente la patria potestad de sus padres.

Al abordar el conflicto que pudiera existir entre el derecho a la vida y el derecho a la libertad religiosa, el Tribunal Constitucional precisa lo siguiente: “(...) la libertad religiosa tiene una doble dimensión, interna y externa. Así, según dijimos en la STC 177/1996, FJ 9), la libertad religiosa «garantiza la existencia de un claustro intimo de creencias y, por tanto, un espacio de autodeterminación intelectual ante el fenómeno religioso, vinculado a la propia personalidad y dignidad individual», y asimismo, «jun- 
to a esta dimensión interna, esta libertad ... incluye también una dimensión externa de agere licere que faculta a los ciudadanos para actuar con arreglo a sus propias convicciones y mantenerlas frente a terceros (SSTC 19/1985, EJ 2; 120/1990, EJ 10, y 137/1990, FJ 8)".

Pero además, esa esfera de agere licere, dice el Tribunal, lo es "con plena inmunidad de coacción del Estado o de cualesquiera grupos sociales" (STC 46/2001, FJ 4, 288/2001 y, en el mismo sentido, las SSTC 24/1982 y 166/1996).

Afirmado que el menor puede ser titular del derecho a la libertad religiosa, la sentencia 154/2002 se pronuncia sobre el significado constitucional de la oposición del menor al tratamiento médico (FJ 9) y lo hace en los siguientes términos: "Más allá de las razones religiosas que motivaban la oposición del menor, y sin perjuicio de su especial trascendencia (en cuanto asentadas en una libertad pública reconocida por la Constitución), cobra especial interés el hecho de que, al oponerse el menor a la injerencia ajena sobre su propio cuerpo, estaba ejercitando un derecho de autodeterminación que tiene por objeto el propio sustrato corporal — como distinto del derecho a la salud o a la vida-y que se traduce en el marco constitucional como un derecho fundamental a la integridad fisica (art. $15 \mathrm{CE}$ )".

Sin perjuicio de lo anterior, se subraya también que la capacidad que el ordenamiento reconoce al menor para determinados actos no es de suyo suficiente para, por vía de equiparación, reconocer la eficacia jurídica de un acto que por afectar en sentido negativo a la vida, tiene, como notas esenciales, la de ser definitivo y, en consecuencia, irreparable, en cuanto conduce con toda probabilidad a la pérdida de la vida. Ello supone que los derechos ejercitados por el menor (derecho a la libertad religiosa y derecho a la integridad física), encuentran un límite por la prevalencia del interés superior del propio menor y el valor de bien jurídico afectado por su decisión (la vida), partiendo también de que no hay datos suficientes que permitieran concluir con certeza que el menor fallecido, hijo de los recurrentes en amparo, de trece años de edad, tuviera la madurez de juicio necesaria para asumir una decisión vital, de manera que dicha decisión no vinculaba a los padres. Independientemente de que éstos no podían desconocer la reacción del menor a la hora de dar una respuesta (FJ 10).

Dicho lo anterior, el Tribunal se pronuncia sobre el juicio ponderativo que lleva a confrontar el derecho a la vida del menor (art. $15 \mathrm{CE}$ ) y el derecho a la libertad religiosa y de creencias de los padres (art. $16.1 \mathrm{CE}$ ). En este punto, considera la sentencia de referencia (FJ 12) que es inconcuso que la resolución judicial autorizando la práctica de la transfusión en aras de la preservación de la vida del menor (una vez que los padres se negaran a autorizarla, invocando sus creencias religiosas) no es susceptible de reparo 
alguno desde la perspectiva constitucional, conforme a la cual es la vida un valor superior del ordenamiento jurídico constitucional (SSTC 53/1985 y 120/1990). Además, reitera lo expuesto en las sentencias 120/1990, de 20 de junio (FJ 7) y 137/1990 (FJ 5) en el sentido de que el derecho fundamental a la vida tiene "un contenido de protección positiva que impide configurarlo como un derecho de libertad que incluye el derecho a la propia muerte". Se reitera en suma que "la decisión de arrostrar la propia muerte no es un derecho fundamental sino únicamente una manifestación del principio general de libertad que informa nuestro texto constitucional, de modo que no puede convenirse en que el menor goce sin matices de tamaña facultad de auto-disposición sobre su propio ser".

Sentado lo anterior, el Tribunal, haciendo uso del principio de proporcionalidad, aborda el problema de las concretas acciones que se exigían a los padres en el caso examinado. Teniendo presente que los padres acataron, desde el primer momento, la decisión judicial que autorizaba la transfusión, descarta el Tribunal la exigibilidad de una acción suasoria sobre el hijo (FJ 15), radicalmente contraria a sus convicciones religiosas, a las convicciones del menor, y desechada por los médicos e incluso por la autoridad judicial, una vez conocida la reacción del menor (comprobado el estado de gran excitación del menor ante la posibilidad de la transfusión, los médicos estimaron muy contraproducente seguir adelante, ante el riesgo de que se precipitara una hemorragia cerebral)".

En cuanto a la jurisprudencia del Tribunal Europeo de Derechos Humanos, que también desgrana el dictamen, cabe destacar las ocasiones en que se ha referido al poder de autodisposición de la persona y a los conflictos surgidos por lo que los recurrentes estiman como injerencias en sus vidas, o conductas contrarias a lo que disponen los artículos 2, 3 y 8 del Convenio, y también, en ocasiones, los artículos 9 y 14. Este es el caso de la sentencia Pretty $\boldsymbol{c}$. Reino Unido, de 29 de abril de 2002, significativa a los efectos del presente dictamen, si bien, en lo sustancial viene a coincidir con la interpretación del Tribunal Constitucional ya expuesta.

La sentencia se refiere a un supuesto en el que una ciudadana británica que padecía una enfermedad neuronal degenerativa incurable (esclerosis lateral amiotrófica) considera violados los artículos antes citados, ante la negativa de las autoridades de su país a garantizar la impunidad de su marido en caso de que éste le auxiliara al suicidio. La respuesta del Tribunal hace notar, entre otros razonamientos, que la interpretación del artículo 2 y del artículo 3 en relación con aquél no ampara la pretensión de la recurrente, que, al invocar su derecho a morir del modo indicado, interpreta de manera forzada, según la sentencia, la expresión «derecho a la vida». En cuanto al maltrato, considera el Tribunal que sólo se daría si se exageraran los medios terapéuticos. 
Conforme con la jurisprudencia sentada en anteriores supuestos, el Tribunal señala que el derecho a la vida no comporta un simple deber de abstención, sino que incluye medidas positivas para su preservación. En este sentido, considera que la prohibición absoluta del suicidio asistido no resulta desproporcionada, dado el peligro que en otro caso concurriría para las personas más dependientes o vulnerables. Por tal motivo el Tribunal concluye que no concurre ninguna de las violaciones denunciadas.

En suma, el Consejo opina que, "a la luz de la jurisprudencia examinada, cabe afirmar que, desde la perspectiva propia de la Constitución Española y del Convenio Europeo de Derechos Humanos, no existe un derecho a morir que forme parte del derecho a la vida y a la integridad fisica y moral. La autodeterminación proyectada sobre la propia vida o la aceptación de la muerte incumbe, como señala el Tribunal Constitucional, a la libertad del individuo y por ello es manifestación del agere licere, que la ley no prohíbe, pero no propiamente un derecho a morir que demande la ayuda de los poderes públicos, como también expresa la jurisprudencia del Tribunal Europeo de Derechos Humanos. Sentado lo anterior, la contestación a la consulta pasa por el análisis de la normativa específica que regula la autonomía del paciente, a la que se dedica el siguiente fundamento jurídico".

De conformidad con lo dicho, el dictamen, en su Fundamento Jurídico IV, pasa a examinar las referencias normativas más importantes que deben ser objeto de consideración para responder a la primera de las cuestiones planteadas por la consulta:

\section{Normativa internacional}

Ante todo, considerando lo dispuesto en el artículo 10.2 de la Constitución, se da por reproducido en este punto lo que disponen la Declaración Universal de los Derechos Humanos de 1948, el Convenio para la Protección de los Derechos Humanos y de las Libertades Fundamentales de 1950 y el Pacto Internacional de Derechos Civiles y Políticos de 1966.

"El análisis de dichos textos-dice el dictamen- no resulta necesario en la medida en que no tratan directamente la cuestión objeto den dictamen y sus determinaciones más generales en relación con los derechos involucrados en este asunto han sido asumidas como punto de partida por el Convenio del Consejo de Europa para la protección de los derechos humanos y la dignidad del ser humano respecto de las aplicaciones de la biología y la medicina, suscrito en Oviedo el 4 de abril de 1997 y vigente en España desde el 1 de enero de 2000.

Ésta es, pues, la referencia normativa más específica que ha de ser objeto de consideración por su directa vinculación con la autonomía del paciente para aceptar o re- 
chazar un tratamiento, que parte de la fundamental premisa de la dignidad del ser humano, a cuya garantía obedece el Convenio de manera fundamental, frente a las prácticas inadecuadas que pueden darse en la biología y la medicina. Con las obligaciones de este Convenio, reflejadas en la legislación estatal y autonómica como a continuación se verá, debe relacionarse la solicitud formulada por doña Inmaculada Echevarría Ramirez”.

En el sentido expresado, hay que comenzar por destacar que el artículo 1 del Convenio de Oviedo dispone que las Partes han de proteger al ser humano en su dignidad y su identidad y garantizar a toda persona el respeto a su integridad y a sus demás derechos y libertades fundamentales con respecto a las aplicaciones de la biología y de la medicina.

"De la regulación del Convenio interesa destacar sobre todo el contenido del capitulo II, cuyo artículo 5 sienta como regla general el consentimiento libre e informado del paciente para la práctica de una intervención en el ámbito de la sanidad; consentimiento que puede ser retirado libremente en cualquier momento.

Las previsiones del artículo 6 con relación al consentimiento por representación, cuando se trate de personas que no tengan capacidad para expresarlo, ya sea por razón de la menor edad, disfunciones mentales u otras enfermedades que lo impidan, no hacen sino reafirmar que las intervenciones sanitarias precisan del consentimiento, salvo excepción legalmente prevista.

Asi lo confirma también la prescripción contenida en el artículo 9 del Convenio para los supuestos de urgencia, de la que se deduce que, sólo cuando no pueda obtenerse el consentimiento adecuado, podrá procederse inmediatamente a cualquier intervención indispensable desde el punto de vista médico en favor de la salud de la persona afectada.

En la misma dirección de respeto de la autonomía del paciente y de su dignidad, hay que subrayar que el artículo 9 establece que serán tomados en consideración los deseos expresados anteriormente con respecto a una intervención médica por un paciente que, en el momento de la intervención, no se encuentre en situación de expresar su voluntad. Las intervenciones coactivas, es decir, en contra de la voluntad del paciente, no tienen cabida en el ámbito del convenio como no sean encuadrables en las "restricciones al ejercicio de los derechos" a las que se refiere el artículo 26.1, las cuales han de ser previstas por la ley y constituir medidas necesarias, en una sociedad democrática, para la seguridad pública, la prevención de las infracciones penales, la protección de la salud pública o la protección de los derechos y libertades de las demás personas”. 


\section{Normativa estatal}

Debe comenzarse por recordar que la Ley 14/1986, de 25 de abril, General de Sanidad, estableció con carácter básico determinados derechos en orden a asegurar una información completa y continuada sobre la asistencia sanitaria y preservar la autonomía de los pacientes de manera que éstos pudiesen ejercer la libre elección entre las opciones presentadas por el responsable médico de su caso y emitir su necesario consentimiento, salvo en los supuestos exceptuados por la propia Ley, y a negarse al tratamiento, excepto en los casos señalados en la propia Ley (art. 10, apartados 5, 6, 8 y 9), en cuyo caso surge la obligación de solicitar el alta voluntaria (art. diez, apdo. 11, y art. undécimo, apdo. 4). Junto a lo anterior, dicha Ley vino a regular los términos del principio de historia clínico-sanitaria única dentro de los límites de cada institución asistencial, el uso y legitimación de acceso a dicha historia y el deber de los poderes públicos de adoptar las medidas precisas para garantizar el derecho del enfermo a su intimidad personal y familiar, así como el deber de secreto de quienes, en virtud de sus competencias, tuvieran acceso a la historia clínica (art. 61).

Los artículos y apartados de la Ley General de Sanidad que se acaban de mencionar quedaron derogados por la Ley 41/2002, de 14 de noviembre, básica, reguladora de la autonomía del paciente y de derechos y obligaciones en materia de información y documentación clínica, pero no porque se estime que las prescripciones contenidas en ellos no son válidas, sino por la necesidad de reforzar los derechos y deberes mencionados, asegurando su efectividad en la línea exigida por el Convenio de Oviedo ya citado.

"Si conviene retener, dice el Consejo, que siguen teniendo reflejo en la Ley General de Sanidad y han de ser respetados por las distintas Administraciones Públicas Sanitarias el derecho a que sea respetada la propia personalidad, dignidad humana e intimidad, sin que quepa discriminación alguna, asi como a la confidencialidad de toda la información relacionada con el proceso del paciente y con su estancia en instituciones sanitarias públicas y privadas que colaboren con el sistema público (art.10, apdos. 1 y 3).

En este orden de ideas, hay que destacar que la propia Ley 41/2002, de 14 de noviembre (cuya condición básica se afirma sobre el artículo 149.1.1. a y 16. de la Constitución) comienza su exposición de motivos subrayando la importancia que tienen los derechos de los pacientes como eje básico de las relaciones clínico-asistenciales, así como la importancia capital que en este ámbito tiene el Convenio de Oviedo, como primer instrumento internacional que se ocupa de la materia con carácter jurídico vinculante para los países que lo suscriben, estableciendo un marco común para la protección de los derechos humanos y la dignidad humana en la aplicación de la biología y de la medicina. 
Aún reconociendo la relevancia y vigencia de los principios recogidos en la Ley 14/1986 para garantizar el máximo respeto a la dignidad de la persona y a la libertad individual, la intimidad personal y la confidencialidad de la información sanitaria, el legislador de 2002 destaca su pretensión de completar, reforzar y concretar los derechos citados, dando un trato especial al derecho a la autonomía del paciente. En esta línea, la exposición de motivos menciona especialmente la regulación sobre instrucciones previas que contempla la Ley de acuerdo con el criterio establecido en el Convenio de Oviedo".

A los efectos del presente dictamen, el examen de la Ley 41/2002, de 14 de noviembre, lleva al Consejo Consultivo a realizar una serie de consideraciones en dos subapartados:

\section{A) Sobre la autodeterminación del paciente y la operatividad del consen- timiento libre, voluntario y consciente en la asistencia sanitaria.}

"En clara continuidad con lo dispuesto en el artículo 10, apartado uno, de la Ley General de Sanidad, la Ley 41/2002 parte del respeto a los principios básicos de la dignidad de la persona humana, autonomía de su voluntad e intimidad, que como tales han de guiar la actividad sanitaria, vinculando a los usuarios, profesionales, centros y servicios sanitarios, sean éstos públicos o privados. Así se evidencia desde el comienzo de su regulación, como demuestra la lectura del artículo 2 y preceptos concordantes.

En efecto, la Ley 41/2002 viene a completar y reforzar, con un tratamiento especifico y pormenorizado, el derecho a la autonomía del paciente, su consentimiento informado y sus deseos e instrucciones previas en relación a cualquier intervención concerniente a su salud.

Con carácter general se puede afirmar que la manifestación libre de voluntad y el previo consentimiento de pacientes y usuarios se constituyen en la clave de bóveda de cualquier actuación en el ámbito de la sanidad. Así se desprende con claridad del artículo 2.2 de la Ley 41/2002, pero también de otra serie de preceptos que parten de una misma orientación, destinada a salvaguardar ese principio fundamental.

La relevancia de la manifestación de voluntad indicada se concreta, expresamente, en diferentes facultades del paciente que participan de esa base común: la posibilidad de consentir o no las actuaciones clinicas sobre su salud (art. 8.1), consentimiento que podrá revocarse libremente, en cualquier momento (art. 8.5); la facultad de decidir libremente entre las opciones clínicas disponibles (art. 2.3); o la negativa misma al tratamiento, salvo en los casos determinados por la ley (art. 2.4). También puede el paciente negarse a recibir información sobre su situación clínica y su estado de salud, con ciertos limites (arts. 4.1 y 9.1). 
Es cierto que la propia Ley permite en su artículo 9.2 que los facultativos puedan llevar a cabo intervenciones clínicas en favor de la salud del paciente, sin necesidad de contar con su consentimiento, pero se trata de intervenciones calificadas como "indispensables" y caracterizadas por circunstancias extraordinarias.

En un primer supuesto, el consentimiento decae ante la necesidad de tutelar un interés general prevalente (riesgo para la salud pública) y sólo en la medida necesaria y con las garantías legalmente previstas. El segundo, es un supuesto extremo donde existe un riesgo inmediato grave para la integridad física o psíquica del enfermo y ni siquiera éste es suficiente para legitimar la intervención, ya que el legislador exige que no sea posible conseguir su autorización, en cuyo caso impone la consulta, cuando las circunstancias lo permitan, a sus familiares o a las personas vinculadas de hecho a él. Por otra parte, el artículo 9.3 de la Ley contempla el consentimiento por representación cuando el paciente no sea capaz de tomar decisiones, a criterio del médico responsable de la asistencia, o su estado físico o psíquico no le permita hacerse cargo de su situación; personas incapacitadas judicialmente o pacientes menores de edad, salvo que estén emancipados o hayan cumplido dieciséis años. Para responder a la consulta planteada, no es necesario analizar con detalle la regulación de estos supuestos, pero en cualquier caso sí hay que hacer notar que son tasados y que el legislador se ha encargado de precisar que la prestación del consentimiento por representación será adecuada a las circunstancias y proporcionada a las necesidades que haya que atender, siempre en favor del paciente y con respeto a su dignidad personal. Además, el paciente participará en la medida de lo posible en la toma de decisiones a lo largo del proceso sanitario (art. 9.5).

En definitiva, la idea capital subyacente a tal regulación normativa es que las prestaciones sanitarias no se pueden imponer contra la voluntad del paciente consciente y $l i$ bre que las rechaza, aunque se trate de una situación de riesgo para la vida.

La normativa expuesta refrenda jurídicamente la convicción de que cualquier intervención médica realizada contra la voluntad del paciente, máxime si se trata de intervenciones agresivas e invasivas desde el punto de vista clínico, atenta y lesiona a la dignidad humana, "fundamento del orden político y de la paz social", según establece el artículo 10.1 de la Constitución Española. Una disposición legal que estableciera la intervención médica coactiva, sin los presupuestos legitimadores a los que se refiere el Convenido de Oviedo, podría incluso incurrir en inconstitucionalidad si llegase a configurar un supuesto de trato inhumano o degradante, en contra de lo establecido en el artículo 15 de nuestra Carta Magna.

Por otra parte, la regulación de las denominadas "instrucciones previas", no hace sino confirmar la relevancia de la autonomía del paciente, aunque en este caso se proyecta sobre actuaciones futuras. En efecto el artículo 11.1 de la Ley 41/2002 dispone 
que mediante el documento de instrucciones previas, una persona mayor de edad, capaz y libre, manifiesta anticipadamente su voluntad, con objeto de que ésta se cumpla en el momento en que llegue a situaciones en cuyas circunstancias no sea capaz de expresarlos personalmente, sobre los cuidados y el tratamiento de su salud o, una vez llegado el fallecimiento, sobre el destino de su cuerpo o de los órganos del mismo. El otorgante del documento puede designar, además, un representante para que, llegado el caso, sirva como interlocutor suyo con el médico o el equipo sanitario para procurar el cumplimiento de las instrucciones previas.

Por su parte, el artículo 11.3 establece que no serán aplicadas las instrucciones previas contrarias al ordenamiento jurídico, a la "lex artis", ni las que no se correspondan con el supuesto de hecho que el interesado haya previsto en el momento de manifestarlas. Además, dispone que en la historia clinica del paciente quedará constancia razonada de las anotaciones relacionadas con estas previsiones. Como se verá después, estas previsiones han sido desarrolladas por la legislación de las Comunidades Autónomas”.

\section{B) Sobre los requisitos y condiciones en que debe operar la autonomía de la voluntad del paciente.}

Sin perjuicio de lo anterior, en todo caso, subraya el dictamen que "la Ley ha establecido un estándar garantista especialmente riguroso en orden a asegurar la manifestación autónoma, libre y consciente de la voluntad del paciente, añadiendo ciertos requisitos y deberes, acordes con la relevancia de las decisiones adoptadas en este ámbito y exigibles también por razones de seguridad juridica:

-Su consentimiento a la actuación médica o su decisión sobre las opciones clínicas disponibles han de ser posteriores y subsiguientes a la recepción, por su parte, de una información adecuada (arts. 2.2. y 8.1). Esta exigencia está en la base misma del denominado "consentimiento informado", como se desprende de la definición del artículo 3 de la Ley.

-El contenido objeto de la información abarcará "toda la información disponible", sobre la correspondiente actuación médica relacionada con su salud y, "como mínimo", la finalidad, naturaleza, riesgos y consecuencias de la misma. (art. 4.1).

-Tanto la calidad de la información -verdadera, comprensible, adecuada a las necesidades del paciente y coadyuvante en la toma de decisiones "de acuerdo con su propia y libre voluntad" (art. 4.2) - como la forma de transmisión de la misma - "verbal" con carácter general, dejando constancia en la historia clinica (art. 4.1)-, están normativamente regladas. 
- La responsabilidad de la información se encuentra expresa y directamente atribuida al médico responsable del paciente y a los demás profesionales intervinientes en el proceso asistencial (art. 4.3).

- La negativa o renuncia a recibir información, derecho reconocido por la Ley (art. 4.1), y limitado por el artículo 9.1, debe ser objeto de manifestación expresa por parte del paciente, haciéndolo constar documentalmente y sin que ello exima de la obligación de obtener su previo consentimiento a la eventual intervención (art. 9.1).

La manifestación de voluntad, libre y consciente, del paciente, en los términos y con el alcance previsto en el artículo 8 de la Ley, ha de tener lugar una vez satisfechas las exigencias antes mencionadas en materia de información; manifestación que, como ya se expuso abreviadamente supra, podrá recoger alguna de las siguientes posibilidades:

-Consentir la actuación concerniente a su salud (art. 2.2).

-Decidir entre las opciones clínicas dispomibles (art. 2.3).

-Negarse al tratamiento, haciéndolo constar por escrito (art. 2.4). En tal caso, el artículo 21 de la Ley establece en su apartado 1 que, en caso de no aceptar el tratamiento prescrito, se propondrá al paciente o usuario la firma del alta voluntaria. Si no la firmara, la dirección del centro sanitario, a propuesta del médico responsable, podrá disponer el alta forzosa en las condiciones reguladas por la Ley. Según dicho precepto, el hecho de no aceptar el tratamiento prescrito no dará lugar al alta forzosa cuando existan tratamientos alternativos, aunque tengan carácter paliativo, siempre que los preste el centro sanitario y el paciente acepte recibirlos (circunstancias que quedarán debidamente documentadas). Asimismo, el artículo 21.2 precisa que, en el caso de que el paciente no acepte el alta, la dirección del centro, previa comprobación del informe clínico correspondiente, oirá al paciente y, si persiste en su negativa, lo pondrá en conocimiento del juez para que confirme o revoque la decisión.

En todo caso, es claro que el referido consentimiento será "verbal", por regla general, y adoptará la forma "escrita" en los supuestos expresamente previstos en la Ley: intervención quirúrgica, procedimientos diagnósticos y terapéuticos invasores y aplicación de procedimientos que supongan riesgos o inconvenientes de notoria y previsible repercusión negativa sobre la salud del paciente (arts. 4.1 y 8, apdos. 2 y 3)-, conteniendo, en tal caso, información suficiente sobre el procedimiento de aplicación y sobre sus riesgos (art. 8.3). En el supuesto de negativa al tratamiento, como se ha anticipado, ésta deberá constar por escrito (art. 2.4). 
Ha de destacarse, finalmente, que la posibilidad de revocación libre y escrita del consentimiento prestado permanece a disposición del paciente en todo momento, tal y como dispone el artículo 8.5 de la Ley. También, por razones obvias, en el caso de haberse emitido documento de instrucciones previas, lo que se deduce de los propios presupuestos de hecho de los que parte el otorgamiento de este documento y se especifica rotundamente por el legislador en el artículo 11.5 de la Ley. Como correlato lógico de los derechos del paciente a los que nos hemos referido, el profesional interviniente está sometido a una triple obligación: correcta prestación de sus técnicas, suministro de la información adecuada y respeto a las decisiones libres y voluntarias del paciente (art. 2.6).

Siendo así, la buena praxis médica, la lex artis, tiene, a partir de tales previsiones legales, una nueva delimitación conceptual y material”.

\section{Disposiciones de la Comunidad Autónoma.}

A) Aún considerando, como parece tener claro el Consejo Consultivo, que no se encuentra vigente en el momento de emisión del dictamen, "no puede dejarse de señalar que el nuevo Estatuto de Autonomía de Andalucía garantiza en su artículo 22 el derecho constitucional previsto en el artículo 43 de la Constitución Española a la protección de la salud mediante un sistema sanitario público de carácter universal (apdo. 1). El apartado 2 del mismo artículo dispone que los pacientes y usuarios del sistema andaluz de salud tienen derecho a ser adecuadamente informados sobre sus procesos de enfermedad y antes de emitir el consentimiento para ser sometidos a tratamiento médico y a la confidencialidad de los datos relativos a su salud.

Asimismo, el Estatuto incorpora una disposición referida al testamento vital y a la dignidad de la persona ante el "proceso de la muerte". Se trata del artículo 20, en cuyo apartado 1 se reconoce el derecho a declarar la voluntad vital anticipada que deberá respetarse, en los términos que establezca la ley. En su apartado segundo, dicho artículo dispone que todas las personas tienen derecho a recibir un adecuado tratamiento del dolor y cuidados paliativos integrales y a la plena dignidad en el proceso de su muerte”.

\section{B) La Ley 2/1998, de 15 de junio, de Salud de Andalucía.}

Arrancando del derecho a las prestaciones y servicios de salud individual y colectiva, de conformidad con lo dispuesto en la normativa vigente, el artículo 6.1 de esta Ley señala también que los ciudadanos son titulares y disfrutan de una serie de derechos. "Entre los más significativos de cara al asunto que nos ocupa, han de citarse, el derecho que tienen al respeto de su personalidad, dignidad humana $e$ intimidad; a la confidencialidad; a la información sobre su proceso incluyendo diagnóstico, pronóstico y alternativas de tratamiento y al acceso a su historial clínico. 
Singularmente, subrayamos el derecho recogido en el párrafo ñ) del mismo artículo y apartado, referido a la libre elección entre las opciones que les presente el responsable médico de su caso y a que se respete su libre decisión sobre la atención sanitaria que se le dispense. A tal efecto será preciso el previo consentimiento escrito del paciente, libremente revocable, para la realización de cualquier intervención sanitaria, excepto en los casos que el propio precepto indica: riesgo para la salud pública; incapacidad del paciente para tomar decisiones, en cuyo caso se actuará según exista o no la declaración de voluntad vital anticipada a la que después nos referiremos. Como una suerte de excepción de la excepción se contempla el supuesto de peligro inminente de lesión grave irreversible o de fallecimiento que exija una actuación urgente, se precisa: "salvo que la declaración de voluntad vital anticipada disponga otra cosa".

Junto a ese derecho y como manifestación también de la autonomía del paciente, el mismo artículo 6.1 proclama en su párrafo p) el derecho a negarse al tratamiento, excepto en los casos antes señalados y previo cumplimiento de lo dispuesto en el artículo 8, apartado 6, que la Ley, precisamente referido al deber de firmar, en caso de negarse a las actuaciones sanitarias, el documento pertinente, en el que quedará expresado con claridad que el paciente ha quedado suficientemente informado y rechaza el tratamiento sugerido.

Del artículo 6.5 se deduce, por otro lado, que tales derechos, sin perjuicio de la libertad de empresa y respetando el peculiar régimen económico de cada servicio sanitario, rigen también en los servicios sanitarios de carácter privado y son plenamente ejercitables"

3. "Aunque en el supuesto examinado no se dan los presupuestos para la aplicación de la regulación jurídica sobre la declaración de voluntad vital anticipada (que, según el expediente, tiene solicitada doña Inmaculada Echevarría Ramírez), el concurso de esta normativa es también fundamental para comprender cuál es la respuesta de la legislación autonómica (como se ha visto también en relación con la legislación nacional) ante las peticiones de los pacientes, conscientes y sin alteraciones de sus facultades psiquicas, en orden a que se les retiren los instrumentos de soporte vital que les mantienen con vida".

Es por ello que se trae a colación la Ley $5 / 2003$, de 9 de octubre, de declaración de voluntad vital anticipada, de la Comunidad Autónoma de Andalucía. $\mathrm{Y}$, aunque posteriormente se referirá esta cuestión, al tratar del testamento vital, es interesante referir lo que dicha Ley regula para el ámbito territorial de la Comunidad Andaluza, que es, al fin y al cabo, el que en este supuesto nos interesa. El objeto de su regulación recae sobre la declaración de voluntad vital anticipada, como "cauce del ejercicio por la persona de su derecho a decidir sobre las actuaciones sanitarias de que pueda ser objeto en el futuro, en el su- 
puesto de que llegado el momento no goce de capacidad para consentir por sí misma" (artículo 1).

El concepto de declaración de voluntad vital anticipada se hace en el artículo 2 que la define como la manifestación escrita hecha para ser incorporada al Registro que la propia Ley crea, por una persona capaz que, consciente y libremente, expresa las opciones e instrucciones que deben respetarse en la asistencia sanitaria que reciba en el caso de que concurran circunstancias clínicas en las cuales no pueda expresar personalmente su voluntad.

En lo que respecta a su contenido, hay que reseñar que el artículo 3 permite al autor de la declaración manifestar "las opciones e instrucciones, expresas y previas, que, ante circunstancias clinicas que le impidan manifestar su voluntad, deberá respetar el personal sanitario responsable de su asistencia sanitaria” (apdo. 1). Dando por reproducido cuanto se dispone en el artículo 4 sobre la capacidad para otorgar la declaración por razón de su trascendencia, ha de señalarse que la Ley exige, además de la apreciación del requisito de capacidad dicho, que la declaración conste por escrito para que sea considerada válidamente emitida.

Independientemente de subrayar la trascendencia de las decisiones que se pueden plasmar en la declaración y, en consonancia con lo anterior, la importancia de la exigencia de plena capacidad para emitirla, hay que dejar constancia de que el artículo 7 dispone que dicha declaración será eficaz, una vez inscrita en el Registro que se crea, de acuerdo con lo establecido en el ordenamiento jurídico, "cuando sobrevengan las situaciones previstas en ella y en tanto se mantengan las mismas”.

La mentada declaración, según el mismo artículo, prevalece sobre la opinión y las indicaciones que puedan ser realizadas por los familiares, allegados o, en su caso, el representante designado por el autor de la declaración y por los profesionales que participen en su atención sanitaria.

No obstante y, al mismo tiempo, la Ley es consecuente y congruente con el significado del principio de autonomía de la voluntad del paciente, al establecer su libre revocación o modificación en cualquier momento, cumpliendo los requisitos exigidos para su otorgamiento (art. 8); prescripción que debe ser interpretada, armónicamente con la legislación básica, como una manifestación de la disponibilidad del paciente, capaz y consciente, sobre decisiones que afectan, de manera más o menos intensa, a bienes tan preciados como la salud o la propia vida, en un supuesto extremo. 
Para el aseguramiento del cumplimiento de dicha voluntad, reversible en todo momento como se acaba de expresar, el artículo 9.2 dispone que cuando se preste atención sanitaria a una persona, que se encuentre en una situación que le impida tomar decisiones por sí misma, en los términos previstos en el artículo 2 de esta Ley, los profesionales sanitarios responsables del proceso consultarán si existe en el Registro constancia del otorgamiento de voluntad vital anticipada y, en caso positivo, recabarán la misma y actuarán conforme a lo previsto en ella.

En este ámbito no deben olvidarse las siguientes leyes autonómicas: Ley 3/2001, de 28 de mayo, de la Comunidad Autónoma de Galicia, reguladora del consentimiento informado y de la historia clínica de los pacientes; Ley 6/2002, de 15 de abril, de Salud de Aragón; Ley de la Comunidad Foral de Navarra 11/2002 de 6 de mayo, sobre los derechos del paciente a las voluntades anticipadas, a la información y a la documentación clínica (modificada por la Ley 29/2003, de 4 de abril); Ley 7/2002, de 12 de diciembre, del País Vasco, de voluntades anticipadas en el ámbito de la sanidad; Ley de la Comunidad Autónoma de La Rioja 9/2005, de 30 de septiembre, reguladora del documento de instrucciones previas en el ámbito de la sanidad y Ley de la Comunidad Autónoma de las Islas Baleares 1/2006, de 3 de marzo, de voluntades anticipadas, y que serán objeto de análisis más adelante.

Sobre la base de todo lo expuesto, el Consejo Consultivo quiere hacer notar "que la regulación básica y autonómica han concebido el principio de autonomía de la voluntad del paciente en unos términos tan amplios que no dejan lugar a dudas sobre la posibilidad de que la falta de consentimiento para una determinada intervención o asistencia, la revocación del mismo o el rechazo de un determinado tratamiento sean decisiones lícitas, aun cuando puedan acarrear situaciones que comprometan gravemente la salud del paciente y lleven incluso a la muerte.

Las previsiones legales descritas en relación con esta materia se han completado en esta línea con la regulación del documento de instrucciones previas en la legislación básica y con la declaración de voluntad vital anticipada en el ámbito autonómico, cuyo alcance, interpretado también a la luz del Convenio de Oviedo, permite comprobar hasta qué punto se ha querido salvaguardar la autonomía de la voluntad de los pacientes y su dignidad, no sólo en la decisión sobre opciones terapéuticas alternativas o el consentimiento de las intervenciones médicas sobre su persona, sino dejando a salvo también la facultad de rechazar el tratamiento que se les ofrezca, todo ello, naturalmente, asumiendo las consecuencias que esa decisión personal comporte, que no podrán trasladarse sobre la Administración Sanitaria, sobre los profesionales intervinientes o terceras personas, obligados a respetar dicha facultad. 
Siendo así, es más que dudosa la polémica nominalista suscitada sobre el asunto sometido a consulta, cuya respuesta no requiere acudir a ambiguas calificaciones terminológicas, ni acudir a experiencias de Derecho comparado muy alejadas del marco juridico en el que aquélla se ha de desenvolver. Si la solicitud de la interesada y lo que ésta demanda de los profesionales de la sanidad que la atienden está amparada por la normativa reguladora de la autonomía y los derechos del paciente frente a los servicios sanitarios, sobran las precisiones terminológicas".

Llegados a este punto, el Consejo Consultivo considera que las normas jurídicas analizadas permiten que cualquier paciente que padezca una enfermedad irreversible y mortal pueda tomar una decisión como la que ha adoptado doña Inmaculada Echevarría. Se trata, según la información obrante en el expediente, de una paciente que padece una enfermedad muscular, incurable, progresiva e irreversible, cuya evolución le ha llevado a una invalidez completa y a depender de un dispositivo artificial (en concreto, un aparato de ventilación mecánica) sin el cual no podría prolongar su vida. La Consejería consultante subraya en este sentido que la paciente ha expresado de forma inequívoca su rechazo al mecanismo de soporte vital, por entender que su situación le causa un sufrimiento insoportable, y que, por tanto, ha solicitado la limitación del esfuerzo terapéutico y reclamado a la Consejería de Salud y al Servicio Andaluz de Salud que garanticen el ejercicio de su derecho a rechazar dicho tratamiento. A lo anterior se añade que la enferma es plenamente consciente de que la retirada de la ventilación mecánica conducirá a su fallecimiento a causa de la enfermedad muscular que padece. En estas circunstancias, el Consejo entiende que se trata de una petición amparada por el derecho a rehusar el tratamiento y su derecho a vivir dignamente, sin estar exceptuada por ninguna de las previsiones legales específicamente examinadas en este fundamento jurídico que permitirían continuar la asistencia médica en contra del consentimiento de la paciente. Siendo así, resulta exigible la conducta debida por parte de los profesionales sanitarios para que sea respetado el derecho de la misma a rehusar los medios de soporte vital que se le aplican.

Es importante señalar que, en opinión del Consejo Consultivo, "parece escasamente fundado el estado de duda generado sobre la solicitud de la paciente, que ha trascendido a los medios de comunicación como un supuesto inédito, excepcional y falto de regulación, cuando realmente no lo es. Por el contrario, este Órgano Consultivo considera respaldada dicha solicitud por la normativa estatal y autonómica examinada, con la consecuencia añadida de que no es posible incardinar la conducta del profesional sanitario que atienda la petición -de conformidad con el deber de respetar el derecho de la paciente que en este sentido se deduce de dicha legislación-en ninguna de las infracciones penales contempladas en el artículo 143 del Código Penal. Con ello se antici- 
pa la respuesta a la segunda cuestión, sobre la base argumental que se expone en el siguiente fundamento jurídico de este dictamen".

Ahora bien, añade el dictamen unas trascendentales precisiones, "sin perjuicio de cuanto se acaba de exponer, hay que subrayar que la respuesta afirmativa a la solicitud de la paciente, con una trascendencia tan extraordinaria que previsiblemente acarreará su fallecimiento casi de inmediato, pasa forzosamente por la comprobación de la existencia de una voluntad firme, cierta, libre y consciente, que en ningún caso puede estar mediatizada por circunstancias endógenas o exógenas, como pudieran ser la perturbación de las funciones cognoscitivas y volitivas o las injerencias externas que pongan en peligro el carácter libre y siempre revocable de una decisión que, por principio, ha de pertenecer a la esfera más íntima y personal del ser humano. Recuérdese, en este sentido, las consideraciones del Tribunal Europeo de Derechos Humanos sobre la justificación de normas que tienden a salvaguardar la vida protegiendo a las personas más débiles y vulnerables (especialmente a las que no están en condiciones de tomar este tipo de decisiones con conocimiento de causa) frente a los actos que tiendan a poner fin a su vida o ayuden a ello.

Tal y como se deduce del Convenio de Oviedo y de la legislación estatal básica y autonómica, hay un estándar mínimo que respetar para asegurar que se cumplen las garantías previstas: Un proceso de información completa y comprensible, que constituye un prius necesario sobre el que se asienta la ulterior decisión consciente y libre de la paciente; la verificación de que se trata de una paciente capaz, sin perturbación de sus capacidades psíquicas, que expresa su voluntad de rechazar el tratamiento sin estar influenciada o mediatizada por terceras personas; y finalmente la constancia escrita, con todas las precisiones deducibles de la indicada legislación.

Son los antecedentes del caso los que permiten comprobar si estamos o no ante la existencia de una voluntad firme y cierta, de una persona capaz y libre y suficientemente informada de la trascendencia de su decisión. En este sentido el Consejo Consultivo no puede, ni está llamado a ello, sustituir el papel que deben desempeñar los profesionales sanitarios en la preservación de estas garantias. Sí hay que destacar, desde las especificas funciones que le son propias, que coincide plenamente con la Comisión Autonómica de Ética e Investigación Sanitarias de Andalucía sobre la necesidad de que se cumplan satisfactoriamente una serie de requisitos relacionados con la información sobre la enfermedad, el tratamiento y sus alternativas, asi como con la constatación de la libertad, consistencia y estabilidad de la decisión tomada. Desde esta óptica, debe llamarse la atención sobre la necesidad de que queden resueltas algunas contradicciones que podrían poner en duda la concurrencia de las condiciones necesarias para expresar válidamente el rechazo a los medios de soporte vital. 
Para comenzar, el Consejo quiere destacar que de la documentación remitida resulta que el D.N.I. cuya copia se adjunta al inicio del expediente se refiere a doña Juana Echevarría Ramirez, cuando la solicitante a la que se refiere el resto del expediente se identifica reiteradamente como doña Inmaculada Echevarría Ramírez. Por otra parte, llama la atención la diferente caligrafía y rúbrica empleada en la declaración de voluntad vital anticipada (10 de noviembre de 2006) y la que se estampa en la solicitud que la interesada dirige a la Consejería de Salud para que se le retire la ventilación mecánica (21 de noviembre de 2006), apreciable a simple vista. Extremos ambos que, aun siendo de carácter formal, deben, sin embargo, ser verificados de manera fehaciente y convenientemente aclarados.

Por otro lado, en el informe de la Unidad de Salud Mental de 28 de noviembre de 2006 se señala que la interesada negó tener desórdenes o tratamientos psiquiátricos personales y familiares, y que la impresión diagnóstica obtenida de la anamnesis fue comprobada en las escalas que se citan. En el informe de un profesor de la Escuela Andaluza de Salud Pública y vocal de la Comisión Autonómica de Ética e Investigación Sanitaria se señala que la filiación completa del proceso que padece la paciente no ha sido completamente realizado por motivos que dicha Comisión desconoce, por lo que resulta aventurado establecer un pronóstico preciso con relación a su estado actual, aunque si cabe afirmar su carácter irreversible y progresivo. Y aunque el informe indica que, aparentemente, la paciente tiene integras las capacidades intelectivas y de relación social, seguidamente se anota: "Sintomas depresivos recidivantes"”.

En este orden de ideas, el Consejo Consultivo, en el ejercicio de su deber de velar, incluso preventivamente, por el estricto cumplimiento de la legalidad, formula una importante consideración: "Aunque ya ha mediado por parte de Doña Inmaculada una petición seria, expresa e inequívoca para que le sea desconectado el respirador, tanto en testamento vital, como en petición ad hoc, posterior a éste, debe pedírsele que la reitere, en las mejores circunstancias posibles de ausencia de interferencia externa a su voluntad.

En efecto, en relación con la libertad, asociada al carácter íntimo y personalísimo de la decisión, y a la consistencia y estabilidad de ésta, el Consejo Consultivo no puede dejar de manifestar su asombro y perplejidad -no exentos de rechazo-por el hecho de que se haya magnificado la petición de la paciente y hayan trascendido datos de elevada sensibilidad que afectan a la intimidad y confidencialidad de la paciente, aun reconociendo que ésta puede haber contribuido a ello, a partir de la comunicación que realiza a los medios informativos en octubre de 2006.

Lo cierto es que se ha abierto un debate que discurre por derroteros alejados del marco jurídico analizado, habiéndose generado un clima poco propicio para la reflexión per- 
sonal e intima sobre una decisión tan trascendental, correspondiendo a la Administración Sanitaria verificar si existen injerencias relevantes o la paciente ha podido sentirse desde entonces presionada por aparición de noticias y reportajes sobre su caso. En cuyo caso, sería exigible garantizar que la maduración de la decisión y su eventual revocación se adoptan fuera de toda perturbación con origen en dichas circunstancias exógenas tan inadecuadas como alejadas de los requerimientos del legislador.

En este contexto, y en relación con la actuación de los profesionales sanitarios a la que se aludirá después desde la perspectiva penal, hay que resaltar la relevancia de las recomendaciones de la Comisión Autonómica de Ética e Investigación Sanitarias, que se mueven también en el plano de las normas deontológicas, correspondientes al plano profesional, y cuya violación ha de ser controlada, y eventualmente sancionada, sólo por la autoridad competente y en relación con el ejercicio profesional, y siempre de acuerdo con el principio de legalidad, que implica la recepción en norma heterónoma de las normas deontológicas con expresa tipificación de la conducta y de la sanción, sin que en materia como ésta quepan, por los principios mismos del derecho sancionador, tipos abiertos o genéricos.

En este caso, las autoridades sanitarias andaluzas, como encargadas de controlar los aspectos deontológicos del ejercicio de la asistencia médica pública, deben velar escrupulosamente que se cumplan todas y cada una de las condiciones exigidas por la indicada Comisión para efectuar la desconexión de la ventilación mecánica, condiciones, que no se olvide, han sido formuladas por unanimidad, en un organismo de plural composición y no dependiente jerárquicamente de la Administración de Salud de Andalucia".

Una última consideración que hace el dictamen del Consejo Consultivo se refiere a la trascendental cuestión de los actos ejecutivos de la desconexión de la ventilación mecánica, que "han de se adoptados observando todas las medidas necesarias para evitar sufrimiento físico y mental a la víctima, incluida si fuera necesario la sedación profunda. En caso contrario, se le estaría dispensando un trato inhumano y degradante que viene expresamente vetado por la Constitución (art. 15) y castigado por el Código Penal como delito contra la integridad moral (artículo 173.1)”.

Una vez que, según el Consejo Consultivo de Andalucía, "han quedado despejadas las cuestiones relativas a los límites de la disponibilidad de la propia vida, y de las condiciones del ejercicio de esta disponibilidad, siempre entendida como una manifestación del agere licere, y no como un derecho a la muerte, ni como derecho subjetivo ni mucho menos como derecho fundamental, debe este Superior Órgano Consultivo fundamentar por qué la actuación de los profesionales sanitarios descrita en el apartado segundo de la consulta de la Excma. Sra. Consejera de Salud no puede ser considerada punible". 
A la vista de lo dispuesto en el artículo 143.4 del Código Penal, concluye el dictamen que ésta es la norma directamente aplicable al caso, debiéndose radicalmente descartar otros posible tipos delictivos, como el previsto en el apartado 2 del mismo precepto, o la omisión del deber de socorro (arts. 195 y 196 $\mathrm{CP}$ ), siendo lo único a dilucidar si la actuación de los profesionales sanitarios descrita en la consulta podría ser objeto de punición atenuada, de acuerdo con el citado apartado 4, o es impune, y bajo qué requisitos en ambos casos.

Para fundamentar su respuesta el Consultivo recuerda algunas premisas, no discutibles, con una mera lectura de la norma penal:

1ª . Como extrema manifestación de que el individuo no tiene derecho a la muerte, pero sí puede disponer de la propia vida, las leyes penales españolas no penalizan al suicida, lo que por obvias razones, sólo se podría hacer en caso de tentativa del mismo.

2a․ La punibilidad del suicidio viene referida tan sólo a formas de participación de terceros en el suicidio de una persona.

$3^{a}$. La punición de los terceros se gradúa de acuerdo con su forma de participación, y ésta viene matizada por la existencia o no de consentimiento de la víctima.

En efecto, en el artículo 143 la pena mas grave viene referida al inductor del suicidio (apdo. 1.), pues genera en el suicida una voluntad de quitarse la vida que no hubiera tenido sin la inducción; la siguiente en gravedad es la del apartado 2, donde ya hay una decisión de la persona de quitarse la vida, y se coopera necesariamente; resulta agravada la punición si la cooperación alcanza carácter ejecutivo (apdo. 3), pues se sustituye activamente la realización de la voluntad del suicida. Radicalmente apartado de los anteriores está el apartado 4 de dicho artículo, donde, siempre que haya consentimiento del suici$\mathrm{da}$, se contempla la conducta de quien "causare o cooperare activamente con actos necesarios y directos" a la muerte de éste, en caso de "enfermedad grave que conduciría necesariamente a su muerte, o que produjera graves padecimientos permanentes y dificiles de soportar"; se trata de los llamados por la inmensa mayoría de la doctrina penal los "supuestos eutanásicos", y como es lógico, es este precepto, y ningún otro, el que ha de interpretar el Consejo a fin de evacuar el segundo punto de la consulta facultativa.

A efectos puramente didácticos, aclara el dictamen, y, en aras de lograr una mayor claridad conceptual, cabría añadir una nueva precisión relaciona- 
da con la clasificación de las diferentes modalidades de eutanasia, generalmente adoptada por la doctrina, en todas las cuales se puede incluir o no la hipótesis del consentimiento del sujeto:

1. Eutanasia activa: actos ejecutivos que suponen un acortamiento de la vida del paciente:

a) Eutanasia activa directa: la conducta va dirigida directamente a producir la muerte (dolo directo).

b) Eutanasia activa indirecta: aceptación de que los medios terapéuticos empleados causarían, con una alta probabilidad, la muerte (dolo eventual).

2. Eutanasia pasiva: la no adopción de medidas tendentes a prolongar la vida o la interrupción del tratamiento médico, en ambos casos, claro está, con resultado de muerte.

Hechas estas precisiones, se podría entrar en el examen de la hipotética punibilidad de la conducta descrita en el supuesto objeto de consulta. El tipo prevé que se "causare o cooperare a la muerte de otro con actos necesarios y directos" (amén del requisito del consentimiento y de las características de la enfermedad, ambas cosas descritas en el mismo tipo y a las que se ha hecho anterior referencia).

Pero, para finalizar su argumentación, dice el Consejo, "con lo acreditado en el expediente, sin perjuicio de la recomendación que se hace, se puede afirmar que la petición de Doña Inmaculada consta como "expresa, seria e inequívoca"; que su enfermedad es grave y necesariamente mortal; y que le produce graves padecimientos permanentes y difíiles de soportar; requisitos éstos que en el precepto penal no son cumulativos, sino alternativos, pero que desgraciadamente concurren ambos en el caso de Doña Inmaculada.

En consecuencia, sólo cabe proceder a la indagación sobre si la conducta de los profesionales sanitarios al proceder a la interrupción de la ventilación mecánica se puede calificar como causación o cooperación activa, necesaria y directa a la muerte de la citada señora. Es evidente que si faltare alguna de las características indicadas de la causación o cooperación, la conducta habría de ser calificada como impune.

En este orden de cosas se ha de decir lo que sigue:

"Causar" la muerte supone la realización de actos ejecutivos dolosamente dirigidos a la producción de la muerte, y que se puedan imputar objetivamente a ellos como causa de la misma. "Cooperar activamente con actos necesarios y directos" constituye una 
conducta de colaboración imprescindible, en los términos del artículo 28 del Código Penal, y a la que se pueda imputar objetivamente el acaecimiento de la muerte. A la vista de lo anterior es claro que resulta punible la eutanasia activa directa, aunque con la atenuación de la penalidad prevista. En cambio, del propio tenor literal del tipo, que exige actos directos, es decir, actos que sin intermediación de otro curso causal provoquen la muerte, deduce la mayoría de la doctrina penal la no punibilidad de la eutanasia activa indirecta, y a fortiori, la de la eutanasia pasiva indirecta.

Con independencia de la anterior conclusión, no ya la mayoría, sino prácticamente la generalidad de la doctrina penal, excluye en todo caso del tipo la eutanasia pasiva indirecta, en la que el resultado muerte es fruto de una omisión, en el sentido penal tradicional de "comisión por omisión”.

En efecto, es bien sabido que una pura omisión nunca es punible en sí, porque una pura omisión no puede desencadenar un curso causal: ex nihilo níhil fit, de acuerdo con el apotegma clásico. Toda omisión punible lo es porque el incriminado tenía un deber de actuar para impedir el resultado; estaba en lo que se llama tradicionalmente en Derecho Penal la "función de garante"; estar en esta función exige la existencia de una norma preceptiva de un comportamiento, norma que en Derecho Penal se contrapone claramente a la norma prohibitiva de una concreta conducta.

Es bien clara la relevancia de la distinción que se acaba de apuntar en el supuesto que nos ocupa: una cosa es matar mediante un acto directo (aun moviéndonos en el caso del 143.4, suministrar una inyección letal es un ejemplo ya clásico en la doctrina penalística), y otra cosa dejar morir por la interrupción de un tratamiento (por ejemplo, dejar de suministrar medicamentos sin los cuales la vida terminaría antes, interrupción de la ventilación mecánica).

En el caso de la eutanasia pasiva consentida, no cabe atribuir a los profesionales sanitarios unos "deberes de garante" (art. 11 del Código Penal), que les lleven a prolongar bajo cualquier circunstancia la vida. Ello equivaldría a ignorar todo cuanto se ha expuesto sobre la autonomía del paciente y las decisiones libres y conscientes de éste, que dichos profesionales están obligados a respetar, aunque no estemos propiamente ante un derecho a la muerte, del cual ya sabemos su inexistencia, sino ante una manifestación legítima del agere licere que lleva a la disponibilidad de la propia vida, en este caso respaldada por el Convenio de Oviedo y por la normativa básica estatal y autonómica, en su configuración concreta de derecho a rechazar el tratamiento o la asistencia médica que se recibe. En tales condiciones los profesionales sanitarios no pueden invadir el terreno de dicha disponibilidad, imponiendo activamente un deber de vivir que no ha podido ser previsto como tal en dicha legislación a partir de la disciplina constitucional. 
La doctrina penal indicada utiliza como ejemplo de irrelevancia penal de la eutanasia por omisión, es decir, la llamada eutanasia pasiva, la adopción de comportamientos que impliquen la interrupción de tratamientos destinados a no prolongar la vida terminal, y entre ellos, muy señaladamente, la acción de desconectar los aparatos que mantienen artificialmente la vida.

Además, es del todo artificioso distinguir, de modo puramente naturalístico, entre los comportamientos que no prolongan la vida mediante la omisión de cualquier tratamiento y aquellos que no la prolongan mediante la interrupción de los medios terapéuticos prestados, aunque ello requiera una acción positiva, que en todo caso debe valorarse normativamente como perteneciente al hecho de no prolongar la vida, es decir, una conducta claramente omisiva.

Es claro, también, con todo lo expuesto, que en el caso de una enfermedad terminal, el curso mórbido es el curso causal determinante de la muerte, y que la suspensión de un tratamiento, aunque acelere aquélla, sólo conduce a producir el resultado ineluctable de manera indirecta, en la medida que lo anticipa, pero sólo en esa medida, que no atenta directamente contra el bien jurídico protegido "vida".

En consecuencia, en el caso que se somete a consulta de este Consejo, la interrupción de la ventilación mecánica es una conducta pasiva e indirecta, que se justifica por la existencia de un deber de respetar la decisión libre y consciente del paciente en tal sentido, amparada por la legislación específicamente reguladora de la asistencia sanitaria, y en consecuencia los profesionales sanitarios que la adopten deben quedar impunes por la razón que se acaba de indicar.

Es más, aun en la hipótesis de que la interrupción de la ventilación mecánica no se considerase conducta pasiva e indirecta, dichos profesionales estarían exentos de responsabilidad criminal por actuar en cumplimiento de un deber y, por tanto, amparados por el artículo 20, apartado séptimo, del Código Penal.

A lo anterior, y a mayor abundamiento, aún deben añadirse algunas observaciones finales, que inciden directamente sobre el caso. En concreto, hay que señalar que la respiración asistida mediante ventilación mecánica no es una actuación médica que consista en un solo acto. Necesita vigilancia, control de funcionamiento del ventilador, mantenimiento de condiciones de asepsia, atención continua a la intubación, con renovación de ésta, y evacuación de secreciones, que, de no llevarse a cabo, provocarían la muerte por asfixia de la paciente. En suma, la ventilación mecánica no es más que un soporte de todo un tratamiento continuado de respiración asistida, es decir, un tratamiento médico continuado, cuya interrupción es siempre una omisión, como acaece en los casos en los que el paciente de cáncer rechaza seguir la quimioterapia, aun sabiendo 
que acelera su muerte, e incluso le priva de alguna remota posibilidad de vida. Es evidente que la no continuación es una omisión, aunque se instrumente, como queda dicho, con una acción positiva, obligada porque la función de garante no puede imponer el deber de vivir.

Para terminar, el Consejo Consultivo reitera que la eventual interrupción de la ventilación mecánica, debe tomar en consideración las cautelas y prevenciones a las que se refiere la última parte del anterior fundamento jurídico, que aqui se dan por reproducidas".

A la vista de todo lo anterior, el Consejo Consultivo, llega a las siguientes conclusiones:

"1. La solicitud de limitación del esfuerzo terapéutico y negativa al tratamiento con ventilación mecánica de Doña Inmaculada Echevarría Ramírez es adecuada a Derecho.

2. La actuación de los profesionales sanitarios que procedan a la desconexión del aparato de ventilación mecánica, una vez cumplidos los requisitos establecidos por la Comisión Autonómica de Ética e Investigación Sanitarias, sin perjuicio de que se atiendan las indicaciones de este Consejo formuladas en el fundamento IV, no puede considerarse punible".

Pero, ante la trascendencia de lo concluido por el dictamen, parece primordial reproducir el voto particular y disidente emitido por uno de los Consejeros, dada la importancia de toda la argumentación jurídica que realiza en pro de la vida y en contra de la desconexión de la ventilación mecánica a la paciente:

"VOTO PARTICULAR disidente que, al amparo de los artículos 23 de la Ley 4/2005, de 8 de abril, del Consejo Consultivo de Andalucía, 22.1, a) y 60.3 de su Reglamento Orgánico, aprobado por Decreto 273/2005, de 13 de diciembre, formula el Consejero Sr. Sánchez Galiana al dictamen de la Comisión Permanente del Consejo Consultivo de Andalucía sobre la Consulta Facultativa planteada por la Excma. Sra. Consejera de Salud de la Junta de Andalucía.

Ante todo, el análisis de las cuestiones planteadas por la Excma. Sra. Consejera de Salud debe partir de la constatación de la existencia de un debate social, en el que se puede apreciar una constante confusión entre diversos conceptos: eutanasia activa, eutanasia pasiva, distanasia, ortotanasia, obstinación terapéutica, limitación o abandono del esfuerzo terapéutico, etc. Debiendo ceñirnos a un estudio jurídico del supuesto en cuestión, el hecho cierto es que, según se manifiesta en la solicitud, y con independencia de su calificación, la paciente, que sufre una distrofia muscular progresiva en fase avan- 
zada, obligada a vivir "enchufada a un respirador", reitera su voluntad de "prescindir del tratamiento de ventilación mecánica que me mantiene con vida, una vida que no deseo que se prolongue por más tiempo de manera artificial", solicitando la limitación del esfuerzo terapéutico: "suspensión del tratamiento de ventilación mecánica con las garantías asistenciales necesarias para permitir que acontezca una muerte serena y sin sufrimiento". Se trata, pues, de "rechazar un tratamiento"-ventilación mecánica-con la clara intención de conseguir su muerte evitando los graves padecimientos soportados-, aunque con la necesaria colaboración del personal médico -desconexión del respirador-.

Debemos, asimismo, al contrastar este supuesto con la legislación vigente, prescindir de un debate ético que tampoco es pacífico. Así, y frente a las consideraciones éticas contenidas en la valoración realizada por la Comisión Autonómica de Ética e Investigación Sanitarias en la reunión celebrada el 15 de diciembre de 2006, en la que excusaron la asistencia doce de sus miembros, favorable a la petición, se podría argüir que la Organización Médico Colegial Española, ya en su Asamblea de 22 de mayo de 1993, consideró que quitar la vida a un paciente mediante una acción que se ejecuta o mediante la omisión de una intervención médica obligada, son acciones igualmente eutanásicas, ya que provocan deliberadamente su muerte. "No existe una eutanasia activa y una eutanasia pasiva. Sólo existe eutanasia, una conducta siempre deontológicamente condenable, encaminada a matar (por acción u omisión) a quien padece una enfermedad incurable o sufrimientos insoportables". Resulta evidente que, en este caso, la paciente, plenamente consciente y lúcida, presenta una dependencia absoluta de la ventilación mecánica y busca deliberadamente su muerte, aunque esta pretensión obliga a implicarse a terceras personas (personal médico). La causa directa e inmediata de su muerte sería la "desconexión" o lo que también denomina "limitación del esfuerzo terapéutico". Y en este sentido, el 16 de octubre de 2006 la paciente manifestaba a la prensa: "lo único que pido es la eutanasia, no es justo vivir asi".

Pero dejando a un lado cuestiones terminológicas y éticas, debemos centrarnos exclusivamente en el análisis jurídico del supuesto examinado, partiendo de la inevitable alusión al texto constitucional y al Estatuto de Autonomía, incidiendo este supuesto, fundamentalmente, en la dignidad de la persona y el libre desarrollo de la personalidad como fundamento del orden político (art. 10.1 Constitución), en el derecho a la vida (art. 15) y en la libertad personal (art. 17).

Las conductas consistentes en el rechazo por el paciente de tratamiento o medidas terapéuticas, dejando que la vida siga su curso natural, tienen - a juicio del Tribunal Constitucional-amparo en el derecho a la integridad física del artículo 15 de la CE, de cuyo contenido esencial forma parte el derecho a negarse a cualquier intromisión en el propio cuerpo. Esta ha sido la posición del TC en sentencias como la 48/1996, de 25 de marzo, en la que se manifestaba que "el derecho a la integridad física y moral no con- 
siente que se imponga a alguien una asistencia médica en contra de su voluntad, cualesquiera que fueren los motivos de esa negativa"; o en la sentencia 154/2002, de 18 de julio, en la que el TC declaraba que “. . . al oponerse el menor a la injerencia ajena sobre su propio cuerpo, estaba ejercitando un derecho de autodeterminación que tiene por objeto el propio sustrato corporal-como distinto del derecho a la salud o a la vida-y que se traduce en el marco constitucional como un derecho fundamental a la integridad fisica (art. 15 CE)". Por todo ello, siendo difícil desde un plano constitucional justificar el deber del Estado de castigar los ataques a la vida humana en los supuestos en que el enfermo decide que la enfermedad siga su curso natural, en el panorama legislativo español se ha procedido a aprobar leyes sobre el "testamento vital" en diferentes CCAA, como es el caso de Cataluña, Madrid, Aragón, Galicia, La Rioja, Extremadura, Navarra y Andalucía (Ley 5/2003, de 31 de octubre y Decreto 238/2004 que regula el Registro de Voluntades Vitales Anticipadas de Andalucía).

Ahora bien, el tema relativo a las conductas por las que se causa deliberadamente la muerte a un enfermo incurable, incluidas también en el genérico derecho a una "muerte digna”, no resulta en absoluto avalado por la jurisprudencia constitucional. Haciendo un repaso al Derecho comparado se advierte que el derecho a la vida está reconocido en todos los textos constitucionales, bien como derecho propiamente dicho que incluye la negación de la pena de muerte o bien como una garantía del respeto de aquella. Por el contrario, no existe ninguna regulación constitucional que reconozca el derecho a la muerte.

La vida es más que un derecho, es un estado inherente a la persona, un valor indisponible que escapa del ámbito de libertad y autonomía de su titular (asi lo han reconocido numerosas resoluciones judiciales). El propio TC (STC 53/1985) ha declarado que los derechos fundamentales y, por tanto, el derecho a la vida, "son los componentes estructurales básicos, tanto del conjunto del orden jurídico objetivo, como de cada una de las ramas que lo integran, en razón de que son la expresión jurídica de un sistema de valores que, por decisión conjunta del constituyente, ha de informar el conjunto de la organización jurídica y politica; son, en fin, como dice el art. 10, el fundamento del orden político y la paz social". El derecho a la vida constituye "el derecho fundamental esencial y troncal en cuanto es el supuesto ontológico sin el que los restantes derechos no tendrian existencia posible”. Por todo ello, el Estado tiene la obligación de protegerla, el ordenamiento jurídico le "impone a los poderes públicos el deber de adoptar medidas necesarias para proteger esos bienes, vida e integridad física, frente a los ataques de terceros, sin contar para ello con la voluntad de sus titulares, e incluso, cuando ni siquiera quepa hablar, en rigor, de titulares de ese derecho" (STC 120/1990, de 27 de junio) Precisamente, este hecho impide un simultáneo reconocimiento del derecho subjetivo a la libre disposición sobre la vida. 
En la STC 120/1990, de 27 de junio (también en la STC 137/1990, de 19 de julio), el TC muestra con claridad su posicionamiento. Por un lado, se niega a entender el suicidio como manifestación del ejercicio del derecho fundamental a la vida en su vertiente negativa. Y por otro, excluye la posibilidad de que la protección constitucional de esta conducta fuera derivable de un supuesto derecho general de libertad o autodeterminación, amparándose en la argumentación de que la libertad como valor superior del ordenamiento (art. $1.1 \mathrm{CE}$ ) no puede operar como fuente de derechos fundamentales distintos de los expresamente recogidos como tales por el texto constitucional. Afirma, además, esta sentencia que "tiene, por consiguiente, el derecho a la vida, un contenido de protección positiva que impide configurarlo como un derecho de libertad que incluya el derecho a la propia muerte". "No es posible admitir, dice el Tribunal Constitucional, que la Constitución garantice en su art. 15 el derecho a la propia muerte”.

Por todo ello, el derecho a terminar con la propia vida de manera activa (con las consiguientes implicaciones que dicho derecho comportaría respecto a las conductas de colaboración) no puede deducirse del tenor literal de la CE, ni entenderlo implícito en ninguno de los derechos fundamentales expresamente consagrados (en la STC 154/2002 el TC declaraba que "la decisión de arrostrar la propia muerte no es un derecho fundamental sino únicamente una manifestación del principio general de libertad que informa nuestro texto constitucional"), ni en una cláusula tan amplia como la dignidad. El artículo 15 no crea a favor del individuo la facultad de libre disposición sobre su vida, de manera que en el ejercicio de esa facultad pudiera llegar a consentir su muerte. Sólo se podría intentar justificar en el principio general de libertad del artículo 1.1 CE, planteamiento éste expresamente rechazado por el TC tal y como se indicaba.

Por su parte, la jurisprudencia del Tribunal Europeo de Derechos Humanos coincide plenamente con la interpretación del Tribunal Constitucional español (véase, por todas, la sentencia Pretty c. Reino Unido, de 29 de abril de 2002), señalando que el derecho a la vida no comporta un simple deber de abstención, sino que incluye medidas positivas para su preservación. La prohibición absoluta del suicidio asistido, según la sentencia citada, no resulta desproporcionada, dado el peligro que en otro caso concurriría para las personas más dependientes o vulnerables.

En suma, en el derecho fundamental a la vida no se puede incluir el derecho a prescindir de la misma.

Es precisamente esta falta de respaldo por parte de la jurisprudencia constitucional al derecho a la muerte, siendo constantes las manifestaciones a favor de la relevancia constitucional del derecho fundamental a la vida, la que ha ocasionado, sin lugar a dudas, la redacción del art. 20 del Estatuto de Autonomía de Andalucía recientemente aprobado. 
En efecto, la redacción original del art. 20.1 del Proyecto de Estatuto de Autonomía establecía: "se garantiza a todos el derecho a morir dignamente". La colisión de este tenor literal con la interpretación jurisprudencial sobre el derecho a la vida, a que acabamos de aludir, ha ocasionado su modificación en el trámite parlamentario. En la actualidad se reconoce, y en consonancia con lo expuesto respecto a las conductas admisibles al amparo del art. 15 de la Constitución-derecho a la integridad física-, el derecho a declarar la voluntad vital anticipada que deberá respetarse, en los términos que establezca la ley, añadiendo el art.20.2 que todas las personas "tienen derecho a recibir un adecuado tratamiento del dolor y cuidados paliativos integrales y a la plena dignidad en el proceso de su muerte".

Ciertamente esta redacción del art. 20 va a amparar el desarrollo de politicas legislativas dirigidas, entre otros temas, a la regulación de los denominados "testamentos vitales" o documentos de instrucciones previas, los cuidados paliativos, o la no prolongación artificial de la vida evitando sufrimientos, medidas que vendrán a plasmar el derecho del paciente a recibir la mejor atención sanitaria en el final de su vida. Pero lo que, en modo alguno, entendemos, podría amparar la redacción de este artículo sería el derecho a decidir sobre la propia vida, prescindiendo de la misma con ayuda de un tercero o de un facultativo sanitario. Una cosa es dignificar el final de la vida y otra muy distinta avalar la autonomía del paciente para decidir el momento en que, en ausencia de las minimas circunstancias exigibles en relación con las voluntades vitales anticipadas - actuaciones sanitarias de que pueda ser objeto en el futuro en el supuesto de que, llegado el momento, no goce de capacidad para consentir por si mismo-, desee deliberadamente morir con ayuda sanitaria. Entendemos que una ayuda médica para suprimir el soporte vital de un paciente, causando deliberadamente la muerte, a petición expresa de éste, no podría ampararse en la redacción del art. 20 del Estatuto de Autonomía. No tiene nada que ver este último supuesto con otras prácticas médicas, en concreto los cuidados paliativos al paciente con el fin de aliviar el dolor aun a riesgo, indirecta e involuntariamente, de acortar su vida; estas prácticas salvaguardan la vida y dignidad del paciente y respetan el proceso natural de su muerte cuando ésta es inminente. Sería, por el contrario, rechazable la directa e intencionada causación de la muerte -desconexión del respirador-, a petición expresa, seria e inequívoca del paciente, aunque estemos ante una enfermedad mortal avanzada o una minusvalía grave crónica.

En el ámbito europeo, debemos destacar la Recomendación no 1418 de la Asamblea Parlamentaria del Consejo de Europa, de 25 de junio de 1999, titulada "Protección de los derechos humanos y de la dignidad de los enfermos terminales y moribundos" la cual insta a los Estados miembros a "adoptar las medidas necesarias para:

I. Reconocer que el derecho a la vida, especialmente en relación con los enfermos terminales o las personas moribundas, es garantizado por los Estados miembros, de acuer- 
do con el artículo 2 de la Convención Europea de los Derechos Humanos, según el cual "nadie será privado de su vida intencionadamente".

\section{Reconocer que el deseo de morir no genera el derecho a morir a manos de un tercero.}

III. Reconocer que el deseo de morir de un enfermo terminal o una persona moribunda no puede, por si mismo, constituir una justificación legal para acciones dirigidas a poner fin a su vida".

Algunos países europeos, a pesar de esta recomendación, han promulgado leyes que han venido a legalizar las conductas que venimos rechazando -así, la Ley holandesa sobre la eutanasia que entró en vigor el 4 de abril de 2002 o la Ley belga de 28 de mayo de 2002, que igualmente despenaliza la eutanasia y reconoce el derecho a elegir la muerte en supuestos de sufrimiento intolerable-. No ha sucedido asi en el caso de España, cuyo ordenamiento jurídico se ha mostrado, hasta el momento, respetuoso tanto con la doctrina del Tribunal Constitucional anteriormente referida, como con las recomendaciones comunitarias.

En efecto, la Ley 14/1986 de 25 de abril, General de Sanidad, en su primitiva redacción, establecía en su artículo 10.6 el derecho del paciente a la libre elección entre las opciones que le presente el responsable médico de su caso, siendo preciso el previo consentimiento escrito del usuario para la realización de cualquier intervención, aunque añadía varias excepciones a esta prestación del consentimiento por escrito, entre las que se encontraba la relativa a "cuando la urgencia no permita demoras por poderse ocasionar lesiones irreversibles o existir peligro de fallecimiento". Y precisamente, el examen de la historia clínica de la paciente en el supuesto que examinamos, pone de manifiesto, salvo error u omisión, la ausencia del consentimiento informado escrito, constando en relación con el ingreso el 2 de enero de 1.997, "tras este ingreso se conecta a ventilación mecánica". Así, desde enero de 1997 está conectada a ventilación mecánica a través de una traqueotomía permanente, aunque no figura en la historia el previo consentimiento escrito, dado, entendemos, que no era necesario, por el peligro de fallecimiento. $Y$ asimismo el derecho a negarse al tratamiento, que figuraba en el apartado 9 del art.10, tenía, entre otros límites, la existencia del peligro de fallecimiento. Resultaba, pues, meridianamente clara la existencia de una serie de límites a los derechos de los pacientes, ejercidos tanto en la sanidad pública como en la privada.

Por su parte, la Ley 2/1998, de 15 de junio, de Salud de Andalucía, cuyo contenido actual resulta de la modificación que tuvo lugar por la Ley 5/2003 de Declaración de voluntad vital anticipada, y en todo caso posterior a la fecha en que se procedió a la conexión del respirador a la paciente, también exige, en su art. 6 letra ñ, y en relación 
a los derechos de los ciudadanos, con respecto a los servicios sanitarios públicos en Andalucía, el consentimiento escrito del paciente, libremente revocable, para la realización de cualquier intervención sanitaria, excepto, entre otros casos, "cuando exista peligro inminente de lesión grave irreversible, o de fallecimiento que exija una actuación urgente, salvo que la declaración de voluntad vital anticipada disponga otra cosa". En el caso en cuestión, resulta evidente no sólo ya la ausencia del consentimiento escrito, sino también la ausencia, en aquel momento, de la declaración de voluntad vital anticipada. Pero es que, además, no podemos olvidar que la voluntad vital anticipada se refiere siempre a actuaciones clinicas que se puedan plantear en momentos en que el afectado no está en condiciones para adoptar decisiones, siendo un instrumento útil para orientar las decisiones médicas, pero sólo será eficaz cuando sus previsiones no sean contrarias al ordenamiento jurídico ni a la lex artis.

Es importante considerar, y asi deriva incluso de los documentos que van a plasmar la declaración de voluntad vital anticipada que se incorporarán al registro de voluntades anticipadas de Andalucía (Decreto 238/2004, de 18 de mayo), que se puede plasmar en la misma el deseo de que "no me sea aplicada ninguna de las medidas de soporte vital, reanimación o cualquier otra con el fin de prolongar mi supervivencia", pero esta instrucción sólo se podrá llevar a cabo en los supuestos contemplados en el apartado segundo, aunque sólo "si en cualquier momento de mi vida futura y como consecuencia de un alto grado de deterioro físico y mental me encuentro en una situación que me impide absolutamente tomar decisiones sobre mi cuidado sanitario y sobre los tratamientos y/o técnicas de soporte vital que se me fuesen a aplicar “. La voluntad vital anticipada se encuadra, pues, en los supuestos de una asistencia sanitaria que va a evitar cualquier ensañamiento terapéutico no deseado en el final de la vida. Pero en modo alguno puede justificar que, en plenas facultades mentales, una paciente que presenta una tetraparesia flácida, manteniendo movilización distal de los dedos que le permite la lectura y el paso de páginas, así como con capacidad fonatoria reducida, pero que le permite la conversación, pueda solicitar "que la dejen morir sin dolor previa sedación y sea desconectada de los mecanismos de respiración artificial”. El supuesto ante el que nos encontramos -suspensión del tratamiento con ventilación mecánica que conducirá necesariamente al fallecimiento, siendo por ello previamente sedada, por petición expresa de la propia paciente-en modo alguno está previsto en la normativa vigente.

Es cierto que la Ley 41/2002 de 14 de noviembre, básica reguladora de la autonomía del paciente y de derechos y obligaciones en materia de información y documentación clínica, ha derogado expresamente los apartados 5, 6, 8, 9 y 11 del art. 10 de la Ley 14/1986, General de Sanidad, aplicables, como hemos indicado, en el momento en que la paciente fue conectada al respirador. Pero ello no es óbice para seguir manteniendo la existencia de unos límites incuestionables al ejercicio de los derechos del paciente. 
En este sentido, el art. 26.1 del Convenio del Consejo de Europa para la protección de los derechos humanos y de la dignidad del ser humano respecto de las aplicaciones de la biología y la medicina, suscrito en Oviedo el 4 de abril de 1997 y vigente en España desde el 1 de enero de 2000, se refiere a las restricciones al ejercicio de los derechos del paciente como medidas necesarias, en una sociedad democrática, para la seguridad pública, la prevención de las infracciones penales, la protección de la salud pública, o la protección de los derechos y libertades de las demás personas.

La autonomía del paciente, configurada en la Ley 41/2002, no es una autonomía ilimitada. Partiendo del evidente reforzamiento de la autonomía del paciente, que se va a plasmar esencialmente en la expresión de sus deseos con anterioridad dentro del ámbito del consentimiento informado que en el caso en cuestión, y según el art. 8.2 debería prestarse siempre por escrito, el art. 2.4, y en el marco de los principios generales, va a establecer que "todo paciente u usuario tiene derecho a negarse al tratamiento, excepto en los casos determinados en la Ley". Y también, el art. 11 que, de acuerdo con el Convenio de Oviedo, va a regular las instrucciones previas atendiendo al respeto de la autonomía del paciente, va a establecer en su apartado 3 que "no serán aplicadas las instrucciones previas contrarias al ordenamiento jurídico...". Y el hecho de que, al fijar los límites del consentimiento informado, no se aluda ya expresamente al caso del peligro de fallecimiento, para justificar la intervención médica, se debe a la regulación en la actualidad de la voluntad vital anticipada, con los efectos a que anteriormente aludimos, pero en modo alguno podrá justificar un consentimiento informado que, tratando de evitar expresamente una intervención médica, pueda resultar contrario al ordenamiento jurídico. Tanto la prestación de un consentimiento informado como su revocación tienen inevitablemente como límite el Ordenamiento jurídico.

El derecho del paciente a rechazar un tratamiento está limitado por la legislación vigente que no sólo evita el hacer daño a terceros, sino también a uno mismo. Para ello previene el suicidio. El rechazo de un tratamiento, que no es ni curativo ni paliativo, sino que constituye el soporte técnico absolutamente necesario para mantener la vida-soporte vital-puede considerarse como una forma de suicidio. La autonomía del paciente, teniendo en cuenta la legislación vigente, no podría en el supuesto examinado, justificar la retirada de un soporte vital. No se podría llegar a forzar el tenor de la Ley de Autonomía del Paciente hasta el punto de justificar la ayuda médica a una negativa a un tratamiento -desconexión del respirador- que va a conducir inexorablemente a la muerte. Y es que, a diferencia de los tratamientos paliativos, que podrían evitar la prolongación artificial de la vida o lo que es igual podrían indirectamente anticipar la muerte, evitando el sufrimiento del paciente, la retirada de un "soporte vital" como el respirador no supone realmente la limitación de un tratamiento o "la limitación de esfuerzos terapéuticos", términos estos últimos que ni siquiera son acuñados por la Ley 41/2002, sino la directa e inmediata causación de la muerte, deseada, en este caso, por la propia 
paciente. No se está realmente rechazando un tratamiento, sino el dispositivo artificial que permite mantener la vida -la vida en cuestión depende de la conexión al respirador-.

Tanto el consentimiento informado, como su revocación, el rechazo del tratamiento o la limitación o abandono del esfuerzo terapéutico - no importa la calificación utilizada- tienen un limite esencial en el ordenamiento jurídico vigente, con importantes consecuencias para los profesionales que lleven a cabo la "desconexión" del respirador si, como se espera, produce como resultado el fallecimiento de la paciente. Estaríamos ante una actuación punible, tipificada en el art. 143.4 del Código Penal.

Efectivamente, tras ser tipificados en los tres primeros números del art. 143 del Código Penal, los delitos de inducción al suicidio, la cooperación al suicidio o la directa producción de la muerte de una persona a petición de ésta, el número 4 del art. 143, va a castigar con una pena menor la siguiente conducta: "El que causare o cooperare activamente con actos necesarios y directos a la muerte de otro, por la petición expresa, seria e inequívoca de éste, en el caso de que la víctima sufriera una enfermedad grave que conduciría necesariamente a su muerte, o que produjera graves padecimientos permanentes y dificiles de soportar, será castigado con la pena inferior en uno o dos grados a las señaladas en los números 2 y 3 de este artículo".

No cabe duda, tal como se desprende de la historia clínica, de que estamos ante una enfermedad grave que conduciría necesariamente a la muerte de la paciente, o que produce graves padecimientos permanentes y difíciles de soportar. Es más, se podría entender que estamos ante una minusvalía grave crónica que supone una dependencia absoluta de los procedimientos o aparatos propios de la medicina intensiva, en concreto el respirador artificial. La persona en estos casos se encuentra imposibilitada físicamente para causarse a sí misma la muerte.

Resulta evidente, por otra parte, la petición expresa, seria e inequívoca de la paciente acerca de su deseo de morir. Precisamente consta el 20 de octubre de 2006 una anotación en la historia clínica que afirma: "La paciente manifiesta en los medios de comunicación su deseo de eutanasia activa”. Y con fecha 21 de noviembre de 2006 solicita expresamente "prescindir del tratamiento de ventilación mecánica, conociendo que consecuencia de ello será su fallecimiento".

El acto "necesario y directo" para conseguir la muerte de la paciente va a ser la desconexión del respirador. Y para evitar el dolor que supondría la muerte por "asfixia" la propia paciente solicita y la Comisión de Etica recomienda la "sedación". No cabe duda del resultado de muerte que se producirá con la desconexión del respirador, por lo que, y también como recomendación de la citada Comisión, deberá "negociarse con la paciente la fecha y hora más adecuada para realizar la suspensión del trata- 
miento", asi como "las personas que desea que estén presentes en el momento de la retirada del tratamiento".

Por último, será el personal sanitario que proceda a la desconexión quien causará o cooperará activamente a la muerte de la paciente. Se podría estimar que el profesional sanitario encargado del paciente va a omitir un determinado tratamiento respiración artificial-dando lugar a la muerte del enfermo, aunque estimamos, compartiendo lo expresado por gran parte de la doctrina penalista, que se puede entender "desconectar" como "actitud activa", siendo punible como acto de cooperación necesaria al suicidio. La consideración de la desconexión del respirador como un "comportamiento activo" derivaría del hecho de que, una vez aplazado el momento de la muerte mediante la conexión, cualquier intervención que revierta esa situación debe considerarse una intromisión activa en un proceso de mantenimiento de la vida en marcha.

Asi pues, en el supuesto en cuestión no estamos ante una anticipación de la muerte como consecuencia secundaria de aplicar un tratamiento paliativo, en una situación de enfermedad de muerte avanzada o minusvalía grave crónica, y con el consentimiento de la paciente, conducta que se podría considerar lícita, sino ante la provocación directa de la muerte, atendiendo a la petición de la paciente, orientada a eliminar sus graves sufrimientos físicos o psíquicos, a través de la desconexión del respirador. Se habría cometido el tipo de homicidio consentido en la modalidad atenuada prevista en el art. 143.4 del Código Penal. Y no cabría aqui la posibilidad de aplicar la causa de justificación del art. $20.7^{\circ}$ del Código Penal relativa al cumplimiento de un deber, dado que, al no tratarse de la aplicación de un tratamiento paliativo, no nos encontraríamos propiamente en el marco de una relación sanitaria asistencial, no siendo relevante el deber de respetar el derecho del paciente a la interrupción de cualquier tratamiento, derecho que, además, vendría limitado por el propio ordenamiento jurídico.

La desconexión del respirador como soporte vital, supone, pues, a nuestro entender, un comportamiento activo que, en el supuesto de enfermedad mortal avanzada o minusvalia grave crónica y con el objetivo de terminar con la situación clínica desfavorable en que se encuentra la paciente, llevado a cabo por petición expresa de ésta, como ocurre en el caso examinado, no sólo constituye un comportamiento que no puede ser exigido a un profesional sanitario, sino que además, constituye una conducta delictiva -homicidio consentido del art. 143.4 del Código Penal- que en modo alguno puede justificarse a través de la causa de justificación de cumplimiento de un deber.

La estabilidad clínica de la paciente no permite estrictamente hablar de enfermedad mortal avanzada, sino más bien de una minusvalía grave crónica, provo- 
cada por una enfermedad incurable y permanente, sin posibilidades fundadas de curación, y dependiendo absolutamente de un respirador como soporte vital. El respirador la puede mantener con vida, consciente y en condiciones de comunicación con el entorno, durante un periodo de tiempo indeterminado. En estas circunstancias, la desconexión del respirador a petición propia, con la finalidad de acabar con sus graves sufrimientos, mediante la directa causación de la muerte, constituiría una conducta punible, que no podría acogerse a ninguna causa que exima de la responsabilidad criminal.

No estamos ante una anticipación de la muerte provocada por un tratamiento paliativo, sino ante una causación directa de la muerte, mediante la supresión de un soporte vital.

En definitiva, y cualquiera que sea la calificación que se pueda otorgar a la actuación médica referida-aplicación de un medio adecuado (desconexión del respirador) con la intención de poner fin a la vida del paciente, por un motivo específico (evitar el sufrimiento)-, y a pesar de haber sido solicitada por la paciente, se trata de una actuación que no se puede considerar amparada por el Ordenamiento jurídico vigente y que, por el contrario, podría ocasionar la iniciación de un procedimiento penal.

La ayuda médica a morir a una persona plenamente consciente no sólo no está legalizada en nuestro país, sino que constituye, por el contrario, una conducta punible que podría originar no sólo y a la condena del personal facultativo que directamente procediese, en este caso concreto, a la desconexión del respirador, sino incluso a una exigencia de responsabilidad a la Autoridad sanitaria que obligase o consintiese la referida actuación de los profesionales sanitarios.

En conclusión, teniendo en cuenta la fundamentación juridica precedente, consideramos que la solicitud de "limitación del esfuerzo terapéutico" y negativa al tratamiento con ventilación mecánica no puede considerarse ajustada a Derecho. No resulta admisible, a nuestro entender, una interpretación forzada o radical de la Ley de Autonomía del Paciente que suponga una exaltación sin límites del principio bioético de la autonomía del paciente, ya que colisionaría directamente con otros elementos de nuestro ordenamiento jurídico, pudiendo acarrear graves consecuencias jurídico-penales, en relación con los profesionales sanitarios que de algún modo participasen en la desconexión del respirador, a pesar de cumplir con los requisitos establecidos por la Comisión Autonómica de Ética e Investigación Sanitarias. Entendemos que ni la Comunidad Autónoma, ni en particular la Consejería de Salud, deberían acceder a algo que no está legalizado por el vigente Ordenamiento jurídico". 


\section{TESTAMENTO VITAL}

"Hase de hablar como en testamento, que a menos palabras, menos pleitos". Baltasar Gracián

Un testamento vital o documento de voluntades anticipadas es la denominación de una manifestación de voluntad anticipada en caso de que la persona no estuviese con facultades para decidir acerca de su tratamiento médico.

Existen múltiples modelos de testamento vital. Pero es significativo el que la Iglesia católica sostiene:

1. Desea que se utilicen todos los tratamientos, medios y cuidados ordinarios o habituales o proporcionados de los que la medicina disponga para obtener la curación aunque sea parcial (distanasia proporcionada).

2. Desea que, si llegara a estar en situación crítica irrecuperable o con insuficiencia total irreversible para la vida autónoma sin asistencia, o en situación de dolores extremos de carácter irreversible, que no se le mantenga artificialmente en vida ni se realicen operaciones quirúrgicas (distanasia desproporcionada).

3. Desea que no se utilicen tratamientos o medios extraordinarios o no habituales o desproporcionados o peligrosos (distanasia desproporcionada), aunque sí los cuidados y las medidas de sostenimiento habituales.

4. Desea que se le administren los tratamientos y cuidados adecuados para paliar los sufrimientos y mejorar la calidad de vida aunque ello suponga un acortamiento de la vida (eutanasia indirecta).

5. Desea que no se le aplique la eutanasia activa o directa ni por acción ni por omisión, ni siquiera en grado de auxilio.

6. Desea que no se prolongue abusiva e irracionalmente su proceso de muerte (encarnizamiento terapéutico o distanasia desproporcionada), es decir, que desea que se le aplique la eutanasia pasiva o indirecta.

7. Desea que en caso de duda interpretativa de su voluntad se atienda a la doctrina enseñada por el Magisterio Pontificio.

Otras organizaciones no religiosas o Administraciones Públicas poseen modelos diferentes de testamento vital, habiendo adquirido estatus legal en 
España. Por ejemplo, conforme a la Ley 21/2000, de 29 de diciembre, vigente en Cataluña, el documento puede firmarse ante notario o ante tres testigos. Dos de ellos no pueden ser familiares en segundo grado ni estar vinculados por relación patrimonial con el otorgante. También es necesario entregarlo al centro sanitario donde la persona deba ser atendida para incorporarlo a su historial clínico.

Un documento tipo suele contener los siguientes puntos especificados con mayor o menor detalle:

"1. Que no se dilate mi vida por medios artificiales, tales como técnicas de soporte vital, fluidos intravenosos, medicamentos o suministro artificial.

2. Que se me suministren los fármacos necesarios para paliar al máximo mi malestar, sufrimiento psíquico y dolor físico causados por la enfermedad o por falta de fluidos o alimentación, aun en el caso de que puedan acortar mi vida.

3. Que, si me hallo en un estado particularmente deteriorado, se me administren los fármacos necesarios para acabar definitivamente, y de forma rápida e indolora, con los padecimientos expresados en el punto 2 de este documento.

4. Los estados clínicos a las que hago mención mas arriba son: a) Daño cerebral severo e irreversible. b) Tumor maligno diseminado en fase avanzada. c) Enfermedad degenerativa del sistema nervioso y/o del sistema muscular en fase avanzada, con importante limitación de mi movilidad y falta de respuesta positiva al tratamiento especifico si lo hubiere. d) Demencias preseniles, seniles o similares. e) Enfermedades o situaciones de gravedad comparable a las anteriores.

5. Designación de un representante para que vigile el documento de las instrucciones sobre el final de mi vida expresadas en este documento, y tome las decisiones necesarias para tal fin.

6. Manifiesto, asimismo, que libero a los médicos que me atiendan de toda responsabilidad civil y penal que pueda derivarse por llevar a cabo los términos de esta declaración.

7. Me reservo el derecho de revocar esta declaración en cualquier momento, en forma oral o escrita." 
Las primeras referencias en nuestro Ordenamiento jurídico a esta figura legal se encuentran en el artículo 10 de la Ley General de Sanidad de 1986, pero cuando, verdaderamente comienza a cobrar vigencia es con la entrada en vigor, el día 1 de enero de 2000, del "Convenio para la protección de los derechos humanos y dignidad del ser humano con respecto a las aplicaciones de la histología y la medicina". El desarrollo de este instrumento no parte del Poder central, sino que será promovido por iniciativas autonómicas, siendo pionera, como ya se ha señalado, la Comunidad Autónoma de Cataluña, a la que seguirán Galicia, Extremadura y Madrid. Hoy la mayor parte de las Comunidades Autónomas han regulado este instituto, sin embargo, a nivel estatal adquiere carta de naturaleza con la Ley 42/2002, de 14 de noviembre, de Autonomía del Paciente.

Algunas de las cuestiones más destacadas sobre la regulación autonómica del testamento vital se encuentran en la Ley $5 / 2003$, de 9 de octubre, de declaración de voluntad vital anticipada, de la Comunidad Autónoma de Andalucía, cuyo objeto es regular, en el ámbito territorial de esta Comunidad, la declaración de voluntad vital anticipada, como "cauce del ejercicio por la persona de su derecho a decidir sobre las actuaciones sanitarias de que pueda ser objeto en el futuro, en el supuesto de que llegado el momento no goce de capacidad para consentir por sí misma" (artículo 1).

La definición de declaración de voluntad anticipada se efectúa en el articulo 2, al considerarla como la manifestación escrita hecha para ser incorporada al Registro que la propia Ley crea, por una persona capaz que, consciente y libremente, expresa las opciones e instrucciones que deben respetarse en la asistencia sanitaria que reciba en el caso de que concurran circunstancias clínicas en las cuales no pueda expresar personalmente su voluntad.

Entrando ya en el contenido propio de la Ley andaluza, debe resaltarse que el artículo 3 permite al autor de la declaración manifestar "las opciones e instrucciones, expresas y previas, que, ante circunstancias clinicas que le impidan manifestar su voluntad, deberá respetar el personal sanitario responsable de su asistencia sanitaria" (apdo. 1). Dando por reproducido cuanto se dispone en el artículo 4 sobre la capacidad para otorgar la declaración por razón de su trascendencia, ha de señalarse que la Ley exige, además de la apreciación del requisito de capacidad dicho, que la declaración conste por escrito para que sea considerada válidamente emitida.

Sin dejar de subrayar la trascendencia de las decisiones que se pueden plasmar en la declaración y, en consonancia con lo anterior, la importancia de 
la exigencia de plena capacidad para emitirla, hay que dejar constancia de algo más:

Que lo relativo a la eficacia de la declaración de voluntades se dispone en el artículo 7, precepto que dispone que dicha declaración será eficaz, una vez inscrita en el Registro que se crea, de acuerdo con lo establecido en el Ordenamiento jurídico, "cuando sobrevengan las situaciones previstas en ella y en tanto se mantengan las mismas". Dicha declaración, según el mismo artículo, prevalece sobre la opinión y las indicaciones que puedan ser realizadas por los familiares, allegados o, en su caso, el representante designado por el autor de la declaración y por los profesionales que participen en su atención sanitaria.

No obstante lo anterior, la Ley es consecuente con el significado del principio de autonomía de la voluntad del paciente, al establecer su libre revocación o modificación en cualquier momento, cumpliendo los requisitos exigidos para su otorgamiento (artículo 8); prescripción que debe ser interpretada, armónicamente con la legislación básica, como una manifestación de la disponibilidad del paciente, capaz y consciente, sobre decisiones que afectan, de manera más o menos intensa, a bienes tan preciados como la salud o la propia vida, en un supuesto extremo.

A fin de conseguir el aseguramiento del cumplimiento de dicha voluntad, reversible en todo momento como se acaba de expresar, el artículo 9.2 dispone que, cuando se preste atención sanitaria a una persona que se encuentre en una situación que le impida tomar decisiones por sí misma, en los términos previstos en el artículo 2 de esta Ley, los profesionales sanitarios responsables del proceso consultarán si existe en el Registro constancia del otorgamiento de voluntad vital anticipada y, en caso positivo, recabarán la misma y actuarán conforme a lo previsto en ella.

Además de la Ley catalana y la andaluza, las demás leyes autonómicas aprobadas sobre cuestión tan relevante como la que nos ocupa, algunas de ellas ya mentadas, son: la Ley 3/2001, de 28 de mayo, de la Comunidad Autónoma de Galicia, reguladora del consentimiento informado y de la historia clínica de los pacientes; la Ley 6/2002, de 15 de abril, de Salud de Aragón; la Ley de la Comunidad Foral de Navarra 11/2002 de 6 de mayo, sobre los derechos del paciente a las voluntades anticipadas, a la información y a la documentación clínica (modificada por la Ley 29/2003, de 4 de abril); la Ley 7/2002, de 12 de diciembre, del País Vasco, de voluntades anticipadas en el ámbito de la sanidad; la Ley de la Comunidad Autónoma de La Rioja 9/2005, de 30 de septiembre, reguladora del documento de instrucciones previas en el ámbito de 
la sanidad y la Ley de la Comunidad Autónoma de las Islas Baleares 1/2006, de 3 de marzo, de voluntades anticipadas.

Algunas de estas normas son igualmente significativas e ilustrativas, dado su grado de detalle, sobre el alcance y la trascendencia de este tipo de declaraciones.

Sirvan a modo de ejemplo, la Ley de la Comunidad Foral Navarra citada en la cual se señala que en las voluntades anticipadas se podrán incorporar manifestaciones para que, en el supuesto de situaciones críticas, vitales e irreversibles respecto a la vida, se evite el sufrimiento con medidas paliativas aunque se acorte el proceso vital, no se prolongue la vida artificialmente por medio de tecnologías y tratamientos desproporcionados o extraordinarios, ni se atrase abusiva e irracionalmente el proceso de la muerte (artículo 9.1).

La Ley de La Rioja llega a referirse al contenido del documento de instrucciones previas, indicando que podrá contener previsiones referidas a la expresión de objetivos vitales, calidad de vida y expectativas personales, así como las opciones personales en cuanto a valores éticos, morales, culturales, sociales, filosóficos o religiosos. Expresión que lógicamente tiene que ver con sus opciones sobre la asistencia sanitaria, concretando, entre otras posibles, las siguientes instrucciones: a) Que se agoten los tratamientos indicados sobre sus dolencias, siempre que no sean desproporcionados en su aplicación o en relación a su previsible resultado; b) Su voluntad contraria a recibir tratamiento de soporte vital; o interrumpir el ya iniciado, cuando éste sea inefectivo para la satisfacción de determinados valores o para mantener una adecuada calidad de vida; c) Su voluntad contraria a que se prolongue temporal y artificialmente la vida si no se acompaña de ningún resultado aceptable para los objetivos del otorgante; d) Su deseo de que se utilicen los procedimientos de sedación y analgesia necesarios para evitar el dolor y el sufrimiento.

\section{A MODO DE EPÍLOGO}

"El resto es silencio"

Hamlet. William Shakespeare

La vida y la muerte son efímeras, sutiles y delicadas, como decía Antonio Machado "La muerte es algo que no debemos temer porque, mientras somos, la muerte no es y cuando la muerte es, nosotros ya no somos". 
Mediante las aportaciones aquí plasmadas simplemente se ha pretendido concienciar sobre la necesidad de reflexionar sobre cómo y de qué formas se deben atajar los problemas jurídicos surgidos desde que, después de su nacimiento, es decir, ostentando ya vida independiente, el propio hecho de vivir enfrenta a los seres humanos con la muerte misma; y sobre la necesidad de perfeccionar los mecanismos jurídicos articulados sobre ello hasta el presente.

La colisión entre las decisiones individuales sobre la posibilidad de decidir sobre la propia muerte y el derecho a la vida y su necesaria protección ha hecho correr ríos de tinta y ha abierto un debate en el que no sólo se combinan aspectos jurídicos sino también éticos, morales y filosóficos, pero no sólo los de aquéllos mismos que desean su muerte, sino también los de los juristas, facultativos y demás personas a las que, por unos u otros motivos, les ha tocado la triste experiencia de estar en esos momentos en los que una persona desea dar el paso de estar con los vivos a estar con los muertos, decisión, sin duda, valiente y dura.

Tema complejo, pues, en el que las decisiones personales se entrecruzan con las decisiones judiciales, médicas, e, incluso penales, y, como no siempre coinciden, la propia autonomía de la voluntad no siempre termina siendo propia ni autónoma. Pero lo cierto es que actualmente nuestro ordenamiento jurídico no permite la realización de conductas que conduzcan a una muerte deseada a los impedidos para hacerlo motu propio. Sobre todo esto hay mucho que opinar no sólo jurídica sino también éticamente, y ello es lo que se ha pretendido hacer en el presente estudio. Aunque en esos delicados momentos en los que se decide querer morir, nunca deberían de dejar de tener presentes algunos pensamientos:

"Sólo merecen vivir los que no tienen miedo a morir". Douglas MacArthur

"La vida no vale nada, pero nada vale una vida". Albert Camus 